Portland State University

PDXScholar

1973

\title{
An Evaluation of a Graduate Social Work Training Program at John Adams High School
}

\author{
George E. Hall \\ Portland State University \\ Guy H. Lutz \\ Portland State University
}

Follow this and additional works at: https://pdxscholar.library.pdx.edu/open_access_etds

Part of the Social Statistics Commons, and the Social Work Commons

Let us know how access to this document benefits you.

\section{Recommended Citation}

Hall, George E. and Lutz, Guy H., "An Evaluation of a Graduate Social Work Training Program at John Adams High School" (1973). Dissertations and Theses. Paper 1701.

https://doi.org/10.15760/etd.1700

This Thesis is brought to you for free and open access. It has been accepted for inclusion in Dissertations and Theses by an authorized administrator of PDXScholar. Please contact us if we can make this document more accessible: pdxscholar@pdx.edu. 
AN EVALUATION OF A GRADUATE SOCIAL WORK TRAINING PROGRAM AT JOHN ADAMS HIGH SCHOOL

by

GEORGE E. HALL

GUY H. LUTZ

A joint project submitted in partial fulfillment of the requirements for the degree of

MASTER OF SOCIAL WORK

Portland State UnIversity

1973 
TABLE OF CONTENTS

PACE

CHAPTER

I INTRODUCTION 1

II AGENCY DESCRIPTION

III TRAINING PROGRAM OBJECTIVE 9

IV EVALUATIVE RESEARCH 13

Definition of Evaluative Research 13

Design for Evaluative Research 13

$\begin{array}{ll}\text { V METHODOLOGY } & 16\end{array}$

$\begin{array}{ll}\text { Population } & 16\end{array}$

Research Objectives $\quad 16$

Development of Questionnaire 17

Administering the Questionnaire $\quad 19$

VI CHARTS AND STATISTICS 22

VII DATA PRESENTATION $\quad 23$

$\begin{array}{lll}\text { VIII SUMMARY AND CONCLUSIONS } & 58\end{array}$

BIBLIOGRAPHY 61

APPENDIX

1 PRETEST CHECKLIST QUESTIONNAIRE 63 
APPENDIX

2. EDUCATION RETRIEVAL-DISSEMINATION CENTER RESULTS

3 QUESTIONNAIRE 
CHAPTER I

INTRODUCTION

This research study is an evaluation of a graduate soctal work training program funded by NIMH of the Department of Health, Education, and Welfare entitled "Teaching-Trainingship Grant in School Social Work." This grant provides training opportunities in a fleld placement at John Adams High School in Portland, Oregon, for Portland State Unfversity School of Social Work Masters degree candidates. Originally approved in June 1969, the grant became operational for the school year $1970-71$.

In addition to faculty salaries, supplies, professional consultation, fees, etc, the grant provides trainee stipends for selected students participating in the program. Both first and second year students in the graduate program are eligible for field placement at John Adams High School where they spend two days per week as school soctal work trainees.

The unit is currently instructed by an MSW soctal worker who is a faculty member of the School of Social Work at Portland State University. The instructor provides a variety of training experfences for students including direct services to clients and families, supervision, consultation, program development, teaching and research. ${ }^{1}$

The primary focus of this study is to evaluate the effectiveness of the training program at Adams High School. Secondartly, this study will attempt to answer three basic questions: 
1. Can a graduate school social work field instruction program in public school social work on the elementary and secondary levels be evaluated?

2. Can an ongoing instrument be developed allowing for evaluation of program and individual instruction?

3. Can the study provide analytical data for the program director's evaluation of the effectiveness of his training? This study was undertaken by the authors because of an interest in program evaluation as an integral function of professional social work practice. We feel agencies, particularly those financed through public funds are increasingly being pressured to not only quantify, but to qualify program effectiveness. Funding bodies now require evaluative research documenting direction and effectiveness of soctal programs.

Findings of this study should be of value not only to the funding source and the program director, but also to other students who in the " future may wish to conduct similar studies in evaluation of graduate social work field instruction.

The following chapter discusses the background and development of John Adams High School and the educational climate that made possible the inclusion of this training program as a part of the learning experiences offered. Chapter III deals with the objectives of the training program. Chapter IV examines evaluative research. Chapter V develops the methodology of the research. 
The charts and statistics used are examined in Chapter VI.

The data are presented and analyzed in Chapter VII. Summary, conclusions and recommendations are then set forth in the final chapter. 
CHAPTER NOTES

1. Grant Proposa1, p. 2 . 
CHAPTER II

\section{AGENCY DESCRIPTION}

John Adams High School opened September, 1969, with approximately 1000 students (grades 9-11). The student body is composed of onequarter Black, and three-quarters White. Adams' co-educational student body is racially integrated. 1

In 1967, a team of students at the Harvard Graduate School of Education wrote a proposal for a clinical high school in which the instruction of students, pre-service and In-service teacher education, basic and applied research, and the development of curriculum would all take place. These doctorial candidates wrote into their proposal provisions for ultimate relations with a university and surrounding community. Then they set about to sell the proposal and themselves; Portland, Oregon bought the proposal and John Adams High School is the result. 2

Three of the original authors became part of the administrative team that developed and helped John Adams become operational. One author remains as Director of Training and Research. 3

The basic philosophy of Adams is substantially different than other secondary schools. John Parker reports this difference in Phi Delta Kappan: 
The original Adams model was based on the analogy of the teaching hospital. This institution in the medical world combines patient care, training, and research in one setting. Our intent for the "clinical high school" was to design an organization which would effectively combine instruction of students with training and research.

The rationale for inclusion of sophisticated personnel training within a school rests squarely on one premise -that the most effective preparation for any profession occurs when trainees carry out specific task, under expert supervision in the actual work setting. ${ }^{4}$

The school continues to operate within the framework of the original philosophy; however, the atmosphere of total student freedom has been somewhat modified. John Adams is basically like a traditional high school in employed personnel, teaching assignment and administrative functioning. However, one unique concept is that of the genera]. education program ${ }^{5}$ whose aim is to provide students with a base of knowledge and a set of communication skills that will be useful to them now as well as when they enter college or the labor market. This general education concept is operationalized through several General Education teams that are responsible for instructing social science curriculum during a major part of the student's daily time block.

The other area that makes Adams unique is its emphasis on the research and training component. There is a full time research staff responsible for the ongoing evaluation concerning the impact of Adams' teaching philosophy and standards on its students and the community. As noted earlier, the training component is extremely important at Adams, and it is within this philosophical framework that the graduate social work NIMH grant and training program was included in the Adams 
concept. In addition to social work trainees, the school also sponsors student teachers, Teacher Corps trainees, and other professional and paraprofessional personnel.

Within the Adams environment the graduate social work trainee works with teachers, counselors, administrators, ful1 time school social workers, and other professional trainee personnel. 
CHAPTER NOTES

1. Grant Proposal, p. 12.

2. "The John Adams Team," Phi Delta Kappan, May 1971, p. 514.

3. Ibid., p. 514 .

4. John L. Parker, "Teacher Training at Adams," Phi Delta Kappan, May 1971, p. 520.

5. Allen L. Dobbins, "Instruction at Adams," Phi Delta Kappan, May 1971, pp. 516-519. 
CHAPTER III

\section{TRAINING PROGRAM OBJECTIVES}

Robert Roy, unit field supervisor, has listed the following goal and objectives as the basis of the social work field experience at John Adams High School.

\section{Goal}

To provide graduate social work students a training experience in social work that meets the needs and interests of the individual student. This will be accomplished through "school social work" in elementary (1-8) and secondary educational settings.

\section{Objectives}

a. To provide training experiences in direct service, consultation, program development, supervision, teaching and research.

b. To provide instruction to graduate students through various methods which include individual and group conferences, tape recordings of group and individual contact with clients, process recordings, modeling field instructor, agency perßonnel, and other soclal work students at John Adams High School.

c. To acquaint students with other resources in the community and how to utilize them in their performance as a school social worker. 
d. To help students gain a better awareness of their self and how this understanding affects their performance as a social worker.

e. To provide training experiences for students in working with minority groups.

f. To expose students to the vital areas of John Adams High School in an effort to determine the effectiveness of that area for the performance of a school social worker.

The expectation of Mr. Roy is that each student at least experience each objective even though the primary area of interest of the student may not lie within several of these particular objectives. It is the aim of graduate level social work education that the student Initially be exposed to several aspects and levels of practice.

The underlying assumption of the grant and program implies that there is a community need for trained school social workers. The community generally provides social work through juvenile courts and public welfare. However, because the educational institution plays such an important part in the psychosocial development of the child, it is imperative that social work trained professionals are available at the school to contend with school related problems as a part of the teacher-counselor-administrator team already functioning to maintain an educational environment conducive to maximum growth.

A variety of services are performed by school soctal workers. These include social casework, group work, consultation with school personnel, teaching, conmunity organization, program development and referral services to community agencles. The school social worker is 
also in a strategic position to help develop resources within the school which strengthen the abilities of the child to cope with persoral and environmental demands.

From the foregoing material it becomes readily apparent that school social work is a specialized area within the profession, and as such requires training geared to the demands of the educational milieu. Statistical evidence will verify the need for trained school social workers.

The report of the developmental task force on Social Work Education and Manpower revealed that in fall of 1964 the public school population of the United States was in excess of 41 million children. Enrollment in public schools by 1970 will approach 45 million. On the basis of one school social worker to each 2,000 school population, by 1970 there will be a need of more than 20,000 social workers. At the present time there are less than 3,000 social workers attached to public schools, leaving a gap of at least $17,000.1$

The NIMH grant and training program is a recognition of this fact that there is an ever increasing demand for we11-trained professionals in school social work. 
CHAPTER NOTES

1. Grant Proposal, p. 16. 
Evaluative research is viewed in terms of an object and a process. Evaluation as an object refers to judgements of social worth or value. If analyzed as a process it implies the degree to which an object is valued. Methodologically, if one is engaged in research of social value that can be measured one would be doing evaluative research. ${ }^{1}$ Evaluative research is also considered as a process which satisfies scientific criteria. ${ }^{2}$ It is also measuring the extent of success toward achieving program objectives. ${ }^{3}$

Evaluative research is viewed as a means of providing guidelines for the practitioner who attempts to assess a program in reference to a particular objective or goal. 4

Edward Suchman believes:

Evaluative research is a specific form of applied research whose primary goal is not the discovery of knowledge but rather a testing of the application of knowledge.

Thus, the major emphasis of evaluative research is upon utility and factfinding concerning a specific planned program.

\section{DESIGN FOR EVALUATIVE RESEÁRCH}

For the purpose of this paper the selected design for evaluative research to be examined is the goal design. Evaluative 
research might include a hypothesis, however, it must include a method of procedure for measuring variations in the attainment of program goals and objectives. ${ }^{6}$ Elizabeth Herzog, in Some Guidelines for Evaluative Research, outlines the following ideas. In the selection of a research design three factors should be considered. One, if the emphasis of the evaluation is specific and has measurable objectives the problem is considered appropriate for the utilization of the goal design.

Two, if the goals of a program are relatively clear, and the nature and availability of data are reliable, then the goal design is a reliable tool.

Three, as a final consideration, the goal design requires personal expertise and a high degree of competence of the researcher in his analysis of data.

After consideration of these criteria it was decided that the goal design is suitable for this research project. The program director specifically requested the examination of program goal and objectives, and the expertise of a research consultant was provided for the development and final analysis of the project. 
CHAPTER NOTES

1. Edwarä A. Suchman, "Principles and Practice of Evaluative Researcin," An Introduction to Social Research, ed. John Doby (New York: Appleton-Cen tury-Crofts, 1967), p. 329.

2. Otto Klineberg, "The Problem of Evaluation," International Social Sclence Bulletin, VII, No. 3 (1955), p. 346.

3. Cecil G. Sheps and Donald L. Madison, Evaluation of Neighborhood Health Centers-A P1an for Implementation, Report to the OEO, Washington, D.C., Ju1y 1967, p. 1.

4. Easley, et a1, Evaluation of the Role of Neighborhood Health Coordinators, 1969 , p. 19.

5. Edward A. Suchman, Evaluative Research (New York: Russell Sage Foundation, 1967), p. 75.

6. Elizabeth Herzog, Some Guidelines for Evaluative Research, U.S. Dept. of Health, Education, and Welfare, Children's Bureau Pub. No. 375 (Washington: U.S. Government Printing Office, 1959), p. 12. 
CHAPTER V

METHODOLOGY

I. POPULATION

The test population was comprised of nine graduate students from the School of Social Work, Portland State University, Portland, Oregon. Of these nine students four were female and five were male, four were second year students and five were first year students, and all were in the age range of 20-35 years. Raclally the group consisted of two Blacks, one Filipino-Hawaitan, one Chicano, one Indian and three Whites. For the school year 1971-1972 these nine students were all that were assigned to Adams by the School of Social Work. Therefore, the test population, although 1imited, represented $100 \%$ of the social work trainees.

\section{RESEARCH OBJECTIVES}

This research project was undertaken in response to the program director's desire to more accurately assess the actualization of his goal and objectives as specified within the NIMH training grant. Mr. Roy listed a goal and several objectives as the basis of social work field experience at John Adams High School. These objectives were then presented in the form of a checklist questionnaire (refer to appendix number 1 ) that ask them to indicate (yes or no) if they felt the objectives were important to their soclal work fleld experience. 
They were then asked to rank in order of importance those 1isted objectives marked "yes." A section was left open for the addition, by the students, of any objectives not listed by the program director. The rationale for this checking of objectives with students was that the consulting researcher felt it important to ascertain student agreement or disagreement with the objectives before the questionnaire could be developed. If the program director and students disagreed widely on program objectives there would have been no common ground from which to develop an evaluative research design. However, the checklist questionnaire reflected a wide area of agreement. The results of this test were then examined by the authors, program director and research consultant to arrive at the goal and objectives used on the final questionnaire.

\section{DEVELOPMENT OF QUESTIONNAIRE}

Out of the foregoing checklist questionnaire results and ensuing discussion, the following goal and objectives were selected for evaiuation in the final questionnaire:

Goal

To provide graduate social work students a training experience in social work that meets the needs and interests of the individual student. This will be accomplished through "school soctal work" in elementary (1-8) and secondary educational settings.

\section{Objectives}

a. To provide training experiences in direct service, consul- 
tation, program development, supervision, teaching and research.

b. To provide instruction to graduate students through various methods which include individual and group conferences, tape: recordings of group and individual contact with clients, process recordings, modeling field instructor, agency personnel, and other social work students at John Adams High School.

c. To acquaint students with other resources in the community and how to utilize them in their performance as a school social worker.

d. To help students gain a better awareness of their self and how this understanding affects their performance as a social worker.

e. To provide training experiences for students in working with minority groups.

f. To expose students to the vital areas of John Adams High School in an effort to determine the effectiveness of that area for the performance of a school social worker.

The questionnaire was constructed on objective base so that responses were limited within the framework provided. Subjective responses were not solicited because objective data more readily lends itself to qualitative analysis.

The questionnaire is composed of six primary objectives. Within each objective are several items that are examined through the following process : 
1. The student is asked if he was provided this experience through the first of three indicators.

2. In the second indicator, if the student replies yes, he is asked to quantify the response by indicating the frequency of this experience; an arbitrary form range scale response was used.

3. The third indicator qualifies the experience, using a fivepoint range scale to indicate the student's subfective evaluation of the benefit derived from the experience item.

Following each component of objective A are a series of supporting quest:ions that allows the student to provide additional information regarding his interest, need and competency in that component area. (These supportive questions are only relevant to objective A.)

\section{ADMINISTERING THE QUESTIONNAIRE}

Because of the length of the questionnaire it was decided to administe:r it in two parts, one a week over two consecutive weeks at the close of the 1971-1972 school year, the rationale being that reliability of test results declines when the testing period extends beyond approximately one-half hour. 1 This timing thus allowed each student a full year of fleld training during which he was exposed to the program goal and objectives he was being asked to evaluate.

For both weeks of testing the written instructions were attached to the questionnaire; verbal instructions were given to clarify any misunderstanding on the part of those being tested and the testers were available to answer any questions during the testing period. 
A separate answer sheet was used in order to facllitate analysis of responses. 
CHAPTER NOTES

1. Don Barr, research consultant. 
CHAPTER VI

\section{CHARTS AND STATISTICS}

Because the test population $(\mathrm{N})$ was limited to nine students any statistical significance is questionable. It was decided to limit the data analysis to percentages that represent frequency of responses to the particular question. These percentages are depicted in chart form in the body of the paper. These are original charts drawn by the authors to more functionally depict the complex data. 
A. To provide training experiences in direct service, consultation, program development, supervision, teaching, and research.

\section{PART 1: DIRECT SERVICES}

OBJECTIVE A

COMPONENT: DIRECT SERVICES

\begin{tabular}{|c|c|c|c|c|c|c|c|}
\hline ITEM & & $\star_{N}$ & ONB & LB & B & $\mathrm{EB}$ & N \\
\hline I. & & 9 & & & 44.44 & 44.44 & 11.11 \\
\hline II. & & 9 & & & 66.67 & 33.33 & \\
\hline III. & & 5 & & & 80.00 & 20.00 & \\
\hline IV. & & 7 & & & 71.45 & 28.58 & \\
\hline v. & & 8 & & & 62.50 & 37.50 & \\
\hline $\begin{array}{l}\text { KEY } \\
\text { ONB } \\
\text { LB }\end{array}$ & $\begin{array}{l}=\text { of No Benefit } \\
=\text { Lacking Benefit }\end{array}$ & $\Sigma=$ & & & 325.06 & 163.85 & 11.11 \\
\hline $\begin{array}{l}\mathrm{B} \\
\mathrm{EB} \\
\mathrm{N}\end{array}$ & $\begin{aligned}= & \text { Beneficial } \\
= & \text { Extremely } \\
& \text { Beneficial } \\
= & \text { Neutral }\end{aligned}$ & $\frac{\Sigma}{5}=$ & & & 65.01 & 32.77 & 2.22 \\
\hline
\end{tabular}


In the direct services component items one and two indicate that all students did have contact with children and families during their training period at John Adams High School, and in item one $88.88 \%$ of the students found the experience to be a rewarding one as represented by the 'beneficial' and 'extremely beneficial' categories. Item two reflects $100 \%$ approval of the experience with an $\mathrm{N}$ of 5 , the third Item designates a feeling among four students that they were not provided assignments working with clients in groups. Of those five experiencing group work, $100 \%$ felt it to be either 'beneficial' or 'extremely beneficial.' Seven out of nine students in item four felt they were provided assignments in diagnosis and treatment, and $100 \%$ of these seven felt these assignments to be 'beneficial' or 'extremely beneficial.' In item five eight students indicated they were provided experience working with other community resources, and again $100 \%$ felt the experience to be 'benefictal' or 'extremely beneficial.'

The percentages for the total direct services component represent a near consensus feeling among the students that the experiences provided by this component were worthwhile. The 'beneficial' category shows $65.01 \%$, and the 'extremely beneficlal' category shows $32.77 \%$, with a neutral response of only $2.22 \%$. Of the five items, however, only two have $100 \%$ affj.rmative responses; so while the overall feeling of the students is that the component was a rewarding experience, there were students who felt they were not provided every item within the direct services component.

The supporting questions show that of the nine students, four were primarily interested in direct services, five said that direct 
direct services was a primary area of their need, and seven students felt more competent in direct services as a result of their experiences at John Adams High School.

DIRECT SERVICES COMPONENT: SUPPORTING QUESTIONS

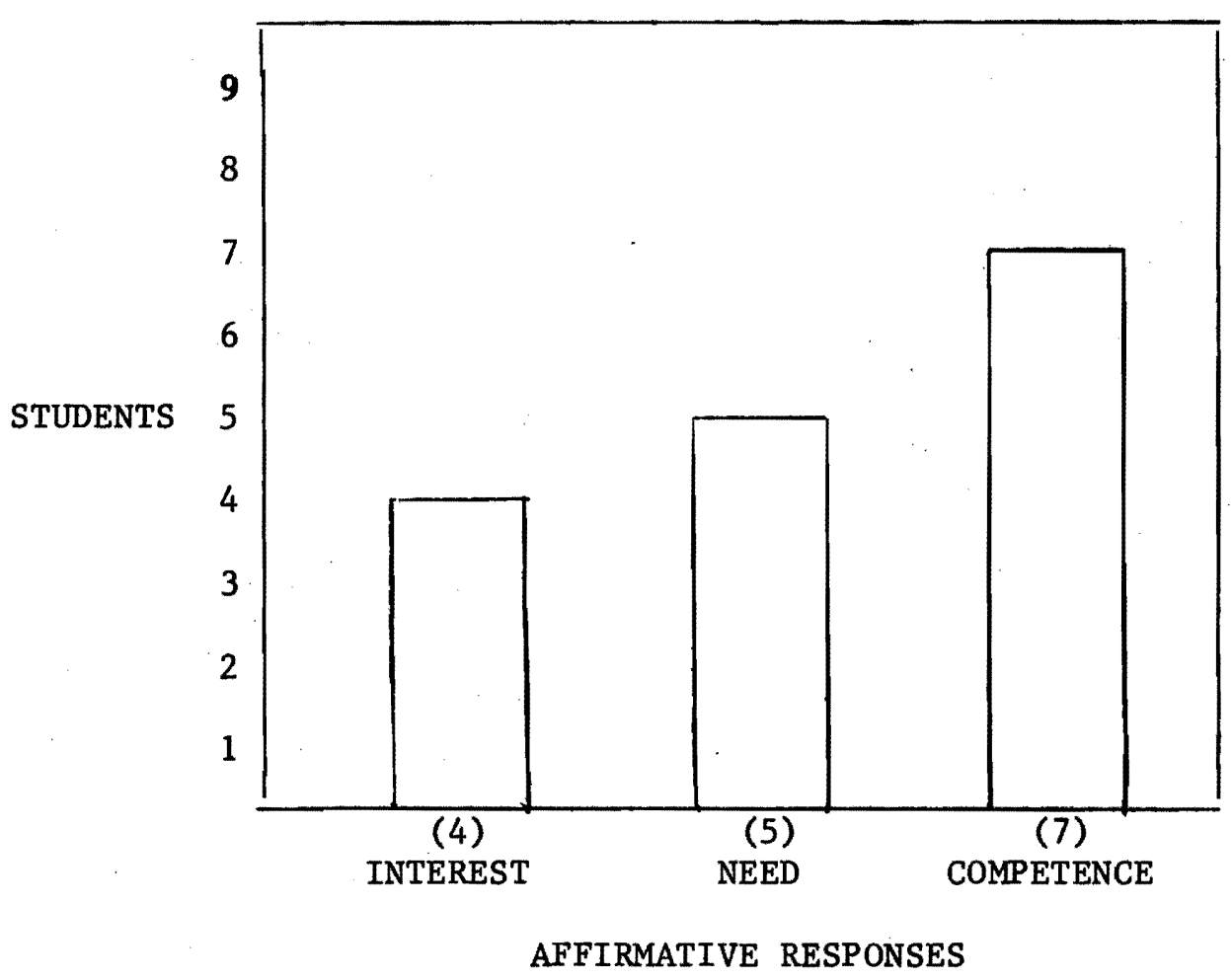


PART 2: CONSULTATION

OBJECTIVE A

COMPONENT: CONSULTATION

\begin{tabular}{|c|c|c|c|c|c|c|}
\hline ITEM & $\mathrm{N}$ & ONB & LB & B & EB & N \\
\hline I. & 9 & & & 55.56 & 33.33 & 11.11 \\
\hline II. & 7 & & & 71.45 & 28.58 & \\
\hline \multirow[t]{3}{*}{ III. } & 6 & & 16.67 & 66.67 & & 16.67 \\
\hline & $\Sigma=$ & & 16.67 & 193.68 & 61.91 & 27.78 \\
\hline & $\xi$ & & 5.56 & 64.65 & 20.64 & 9.26 \\
\hline
\end{tabular}

Item one of the consultation component indicates that $100 \%$ of the students were provided consultation experience working with teachers and other school personnel regarding clients, and of these students 88. $89 \%$ found the experience to be 'beneficial' or 'extremely beneficial.' In the second item seven out of nine students felt they were provided experience working with personnel of other agencles regarding clients, and $100 \%$ of these people found the experience either 'beneficial' or 'extremeily beneficial.' In the third item six of the nine students felt that in consultation they were provided experiences in instruction by the field instructor or other personnel provided by the field instructor in consultation. of these six students, $66.67 \%$ found the experience 
to be 'beneficial' while $16.67 \%$ felt it to be 'lacking benefit,' and $16.67 \%$ were neutral.

The percentages for the total component reflect that $85.20 \%$ of the responding students found the consultation experience to be either 'beneficlal' or 'extremely beneficial,' while $5.56 \%$ felt the experiences to be 'lacking benefit.' $9.26 \%$ felt the experiences to be 'neutral.'

The supporting questions show that of the nine students two were interested primarily in consultation. Four said that consultation was a primary area of their need, and five students felt more competent in consultation at the end of their training at Adams.

CONSULTATION COMPONENT: SUPPORTING QUESTIONS

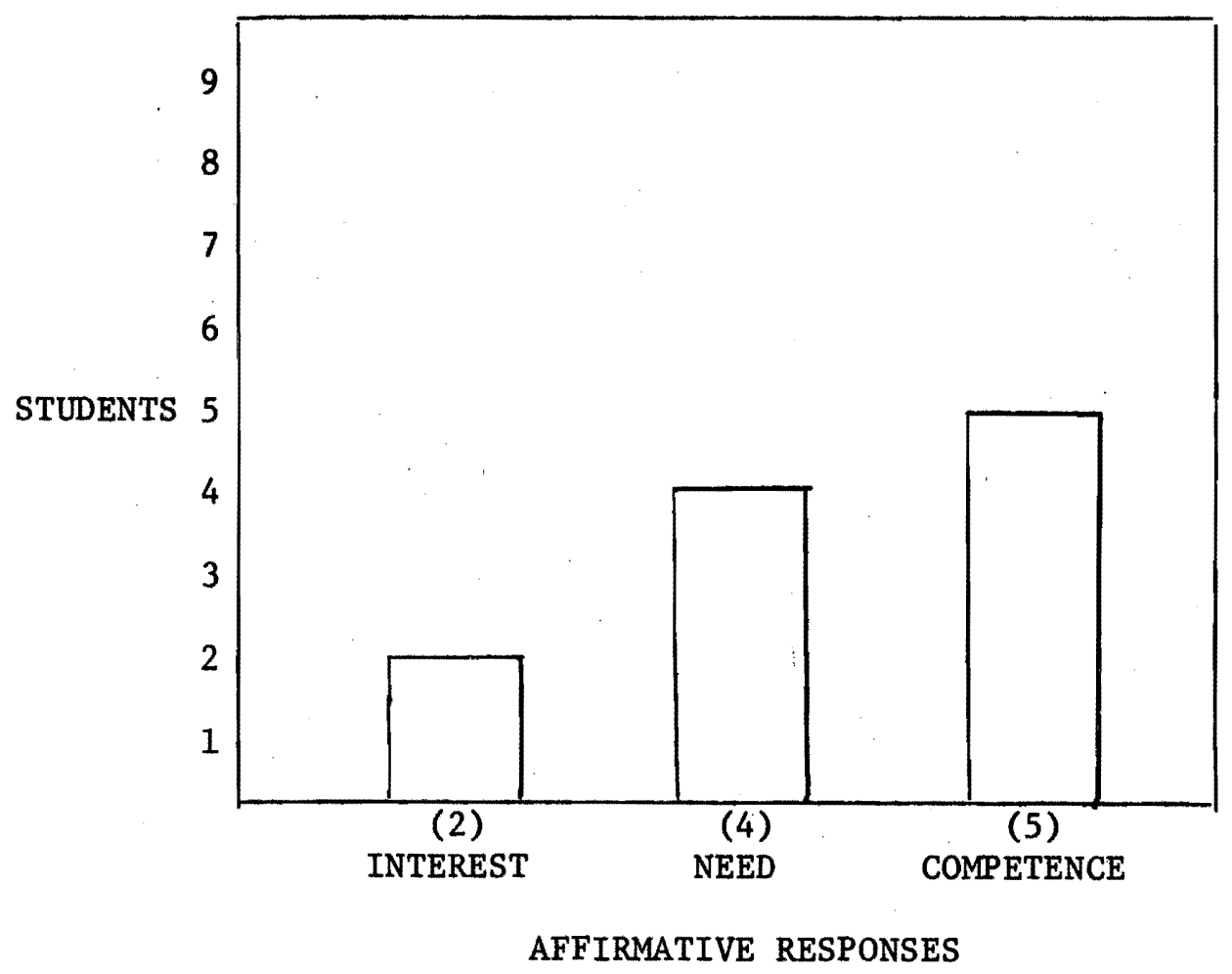


PART 3: PROGRAM DEVELOPMENT

OBJECTIVE A

COMPONENT: PROGRAM DEVELOPMENT

\begin{tabular}{|c|c|c|c|c|c|c|}
\hline ITEM & $\mathrm{N}$ & ONB & LB & B & $\mathrm{EB}$ & $\mathrm{N}$ \\
\hline I. & 5 & & 20.00 & 20.00 & 60.00 & \\
\hline \multirow[t]{3}{*}{ II. } & 5 & & 20.00 & 60.00 & 20.00 & \\
\hline & $\Sigma=$ & & 40.00 & 80.00 & 80.00 & \\
\hline & $\Sigma / 2=$ & & 20.00 & 40.00 & 40.00 & \\
\hline
\end{tabular}

For the two items composing the program development component, five out of nine students responded affirmatively to the questions

"did you develop any program(s) to meet the needs of clients?", and "was any instruction provided by your fleld instructor... in program development?". In both items $80 \%$ of these students felt the experience to be elther 'beneficial' or 'extremely beneficial,' and $20 \%$ found it to be 'lacking benefit.'

The percentages for the total component of program development indicate that $40 \%$ of the students responded in the 'beneficial' category, $40 \%$ in t:he 'extremely beneficial' category, and $20 \%$ in the 'lacking benefit' category. 
The supporting questions show that of the nine students, four sald that program development was both the primary area of their interest and their need, and five students felt they were more competent in consultation at the finish of their training at Adams.

PROGRAM DEVELOPMENT COMPONENT: SUPPORTING QUESTIONS

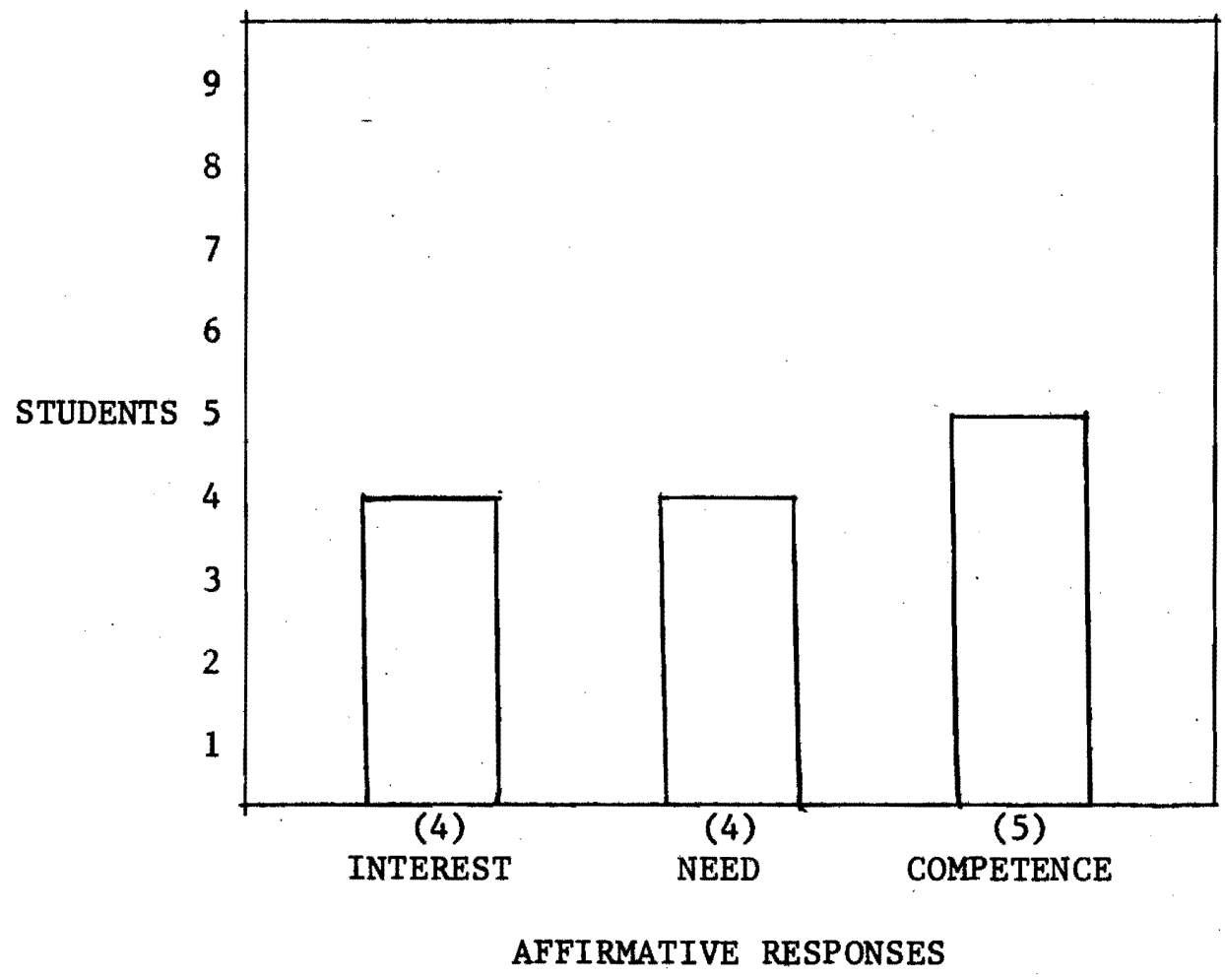


PART 4: SUPERVISION

OBJECTIVE A

COMPONENT: SUPERVISION

\begin{tabular}{|c|c|c|c|c|c|c|}
\hline ITEM & $\mathrm{N}$ & ONB & LB & B & EB & $\mathrm{N}$ \\
\hline I. & 2 & & & & 100.00 & \\
\hline \multirow[t]{3}{*}{ II. } & 4 & & & 25.00 & 50.00 & 25.00 \\
\hline & $\Sigma=$ & & & 25.00 & 150.00 & 25.00 \\
\hline & $\Sigma /=$ & & & 12.50 & 75.00 & 12.50 \\
\hline
\end{tabular}

In Item one of the supervision component, only two students said they had any experiences supervising other agency personnel or soclal work students while at John Adams High School, and both of these students found the experience an 'extremely beneficial' one. Four students responded affirmatively to the question "did you receive any instruction by your field instructor or other personnel provided by your field instructor in supervision?", and $75 \%$ responded in the categories 'beneficial' or 'extremely beneficlal,' while $25 \%$ responded in the 'neutral' category.

The overall component percentages reflect $87.50 \%$ in the 'beneficial' and 'extremely beneficial' categories, with $12.50 \%$ in the 'neutral' category. 
The supporting questions show that of the nine students three said supervision was the primary area of their interest. Five students sald supervision was a primary area of need, and four students felt more competent in supervision after their year of training.

SUPERVISION COMPONENT: SUPPORTING QUESTIONS

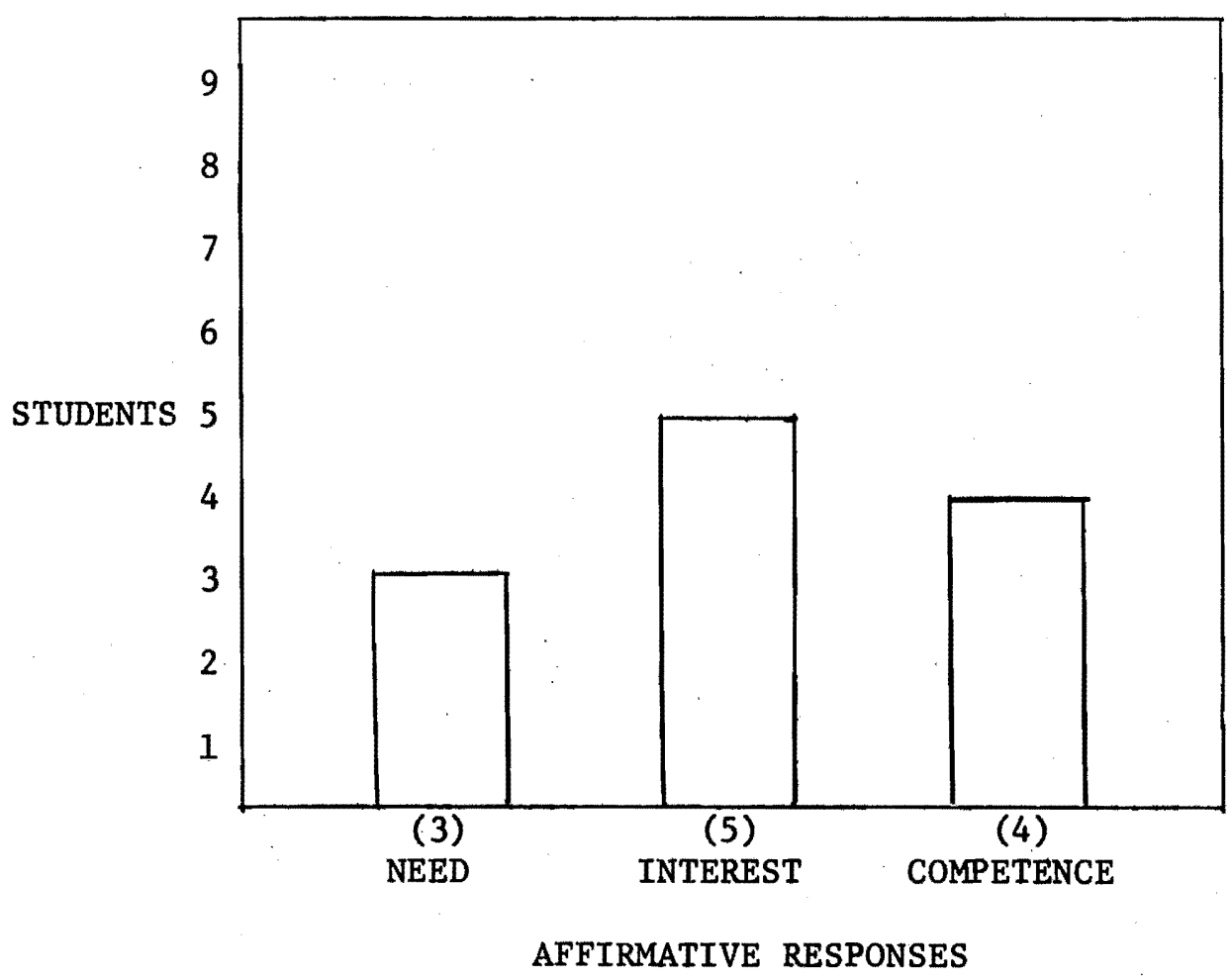


PART 5: TEACHING

OBJECTIVE A

COMPONENT: TEACHING

\begin{tabular}{|c|c|c|c|c|c|c|}
\hline ITEM & $N$ & ONB & LB & B & $\mathrm{EB}$ & $\mathrm{N}$ \\
\hline I. & 2 & & & & 100.00 & \\
\hline II. & 2 & & & 50.00 & 50.00 & \\
\hline & $\Sigma=$ & & & 50.00 & 150.00 & \\
\hline & $\Sigma / 2=$ & & & 25.00 & 75.00 & \\
\hline
\end{tabular}

In the teaching component, items one and two, two out of nine students had experiences in teaching and received instruction in teaching. $100 \%$ of the students felt their experiences in teaching were either 'beneficial' or 'extremely beneficial.' The percentages for the total teaching component represents a $100 \%$ consensus feelirg among the two students that their experiences in teaching were 'beneficial' or 'extremely beneficlal.'

The supporting questions show that of the nine students, two sald teaching was their primary interest, three said teaching was their primary need, and two felt more competent after their experiences at John Adams High School. 
TEACHING COMPONENT: SUPPORTING QUESTIONS

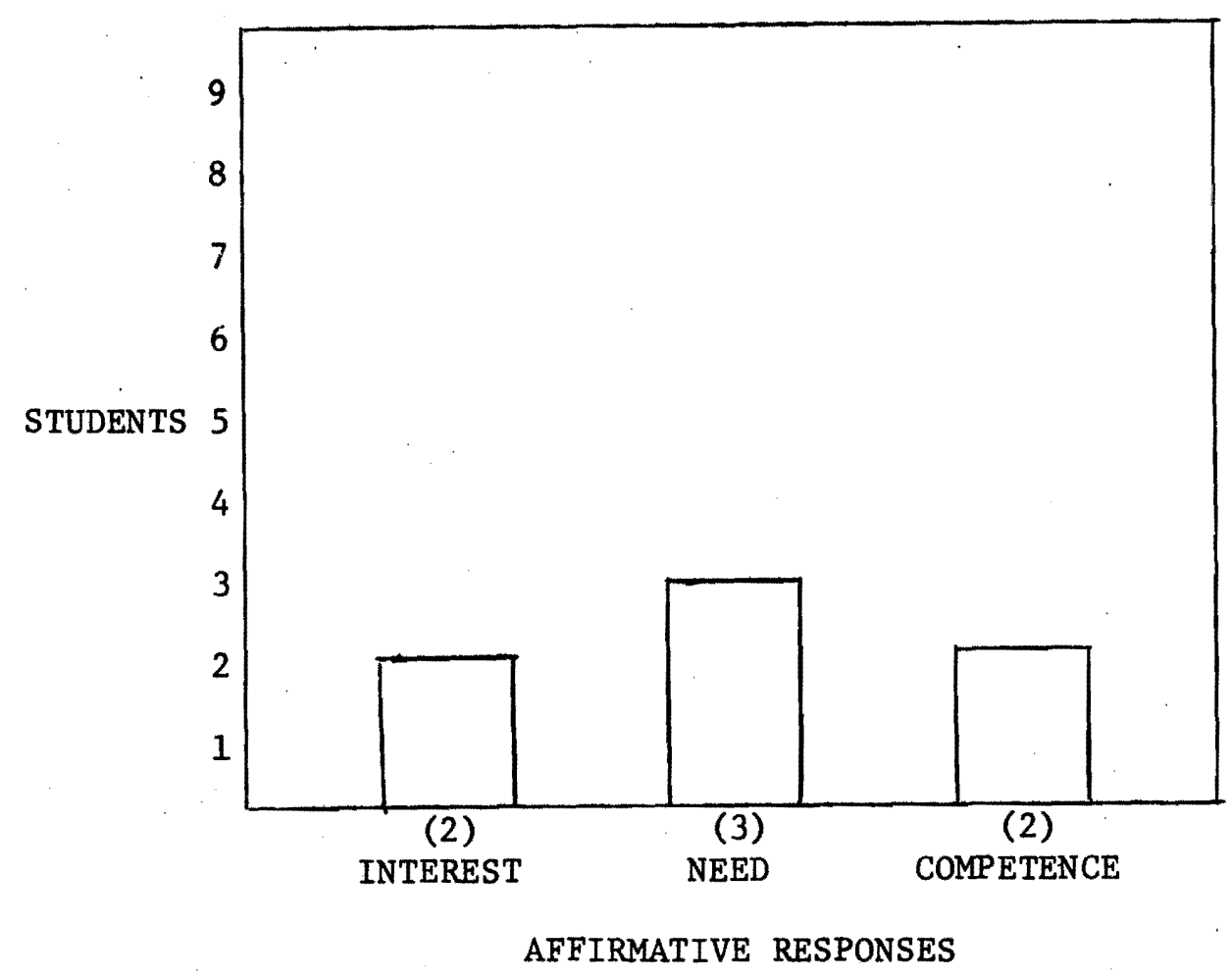


PART 6: RESEARCH

OBJECTIVE A

COMPONENT: RESEARCH

\begin{tabular}{|c|c|c|c|c|c|c|}
\hline ITEM & $\mathrm{N}$ & ONB & LB & B & $E B$ & $\mathrm{~N}$ \\
\hline I. & 3 & & 33.33 & 33.33 & 33.33 & \\
\hline II. & 2 & & 50.00 & & 50.00 & \\
\hline & $\Sigma=$ & & 83.33 & 33.33 & 83.33 & \\
\hline & & & 41.67 & 16.67 & 41.67 & \\
\hline
\end{tabular}

In the research component three out of nine students did research and two out of nine students received instruction in research. of the three students who did research $33.33 \%$ felt their experiences were 'lacking benefit' and $66.66 \%$ felt their experiences were 'beneficlal' or'extremely beneficial.' of the two students who received teaching in research, $50 \%$ felt the experiences were 'lacking benef1t,' and $50 \%$ felt the experiences were 'extremely beneficlal.'

The supporting questions show that of the nine students one said research was the primary area of his interest, no student felt research to be a primary area of his need, and one student felt more competent as a result of his research training at John Adams High School. 
RESEARCH COMPONENT: SUPPORTING QUESTIONS

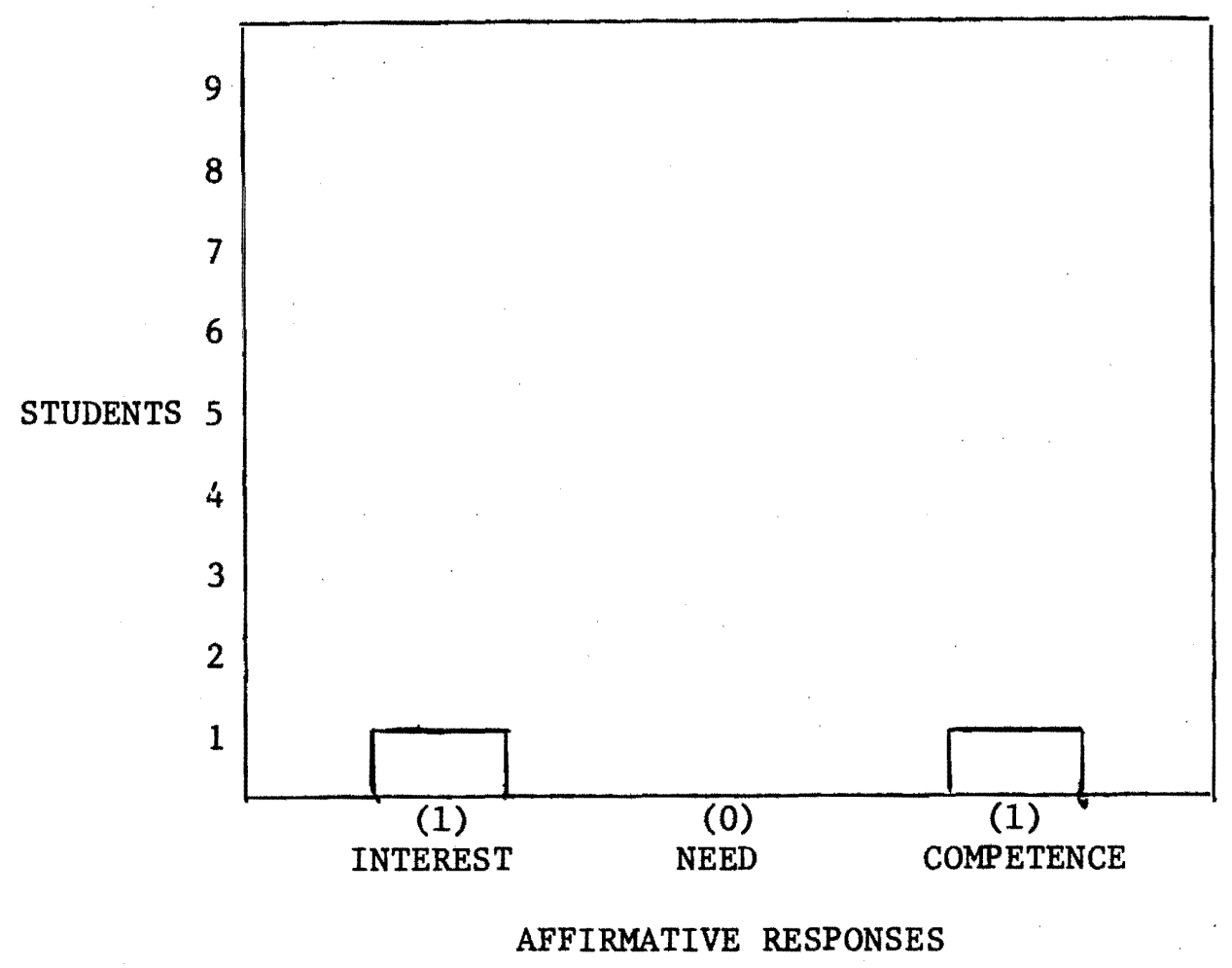


PART 7: OBJECTIVE A SUMMARY

OBJECTIVE A

SUMMARY

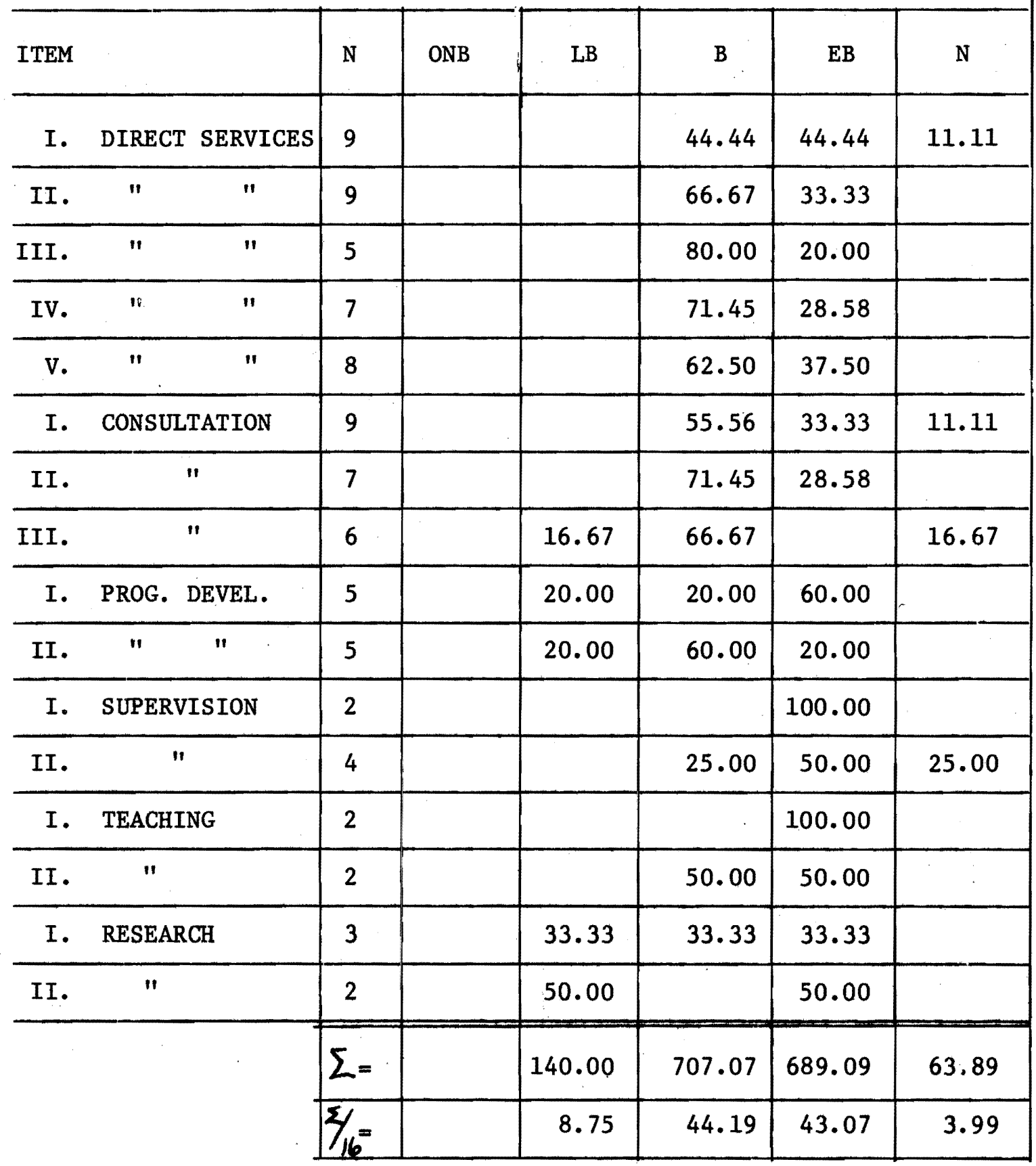


To singularly analyze objective $A$ the various category percentages of each component item were totaled and divided by the total number of items (16) to provide the mean analysis of the total objective. Of all the students that experienced each item $8.75 \%$ felt their experiences with objective A 'lacking benefit,' $3.99 \%$ of the students felt their experiences were 'neutral,' $44.19 \%$ of the students felt their experiences were 'beneficial,' and $43.07 \%$ of the students felt their experiences in objective A were 'extremely beneficial.'

The following bar graph is a summary depicting information presented in the preceding six component supporting questions bar graphs (pp. 25, 27, 29,31, 33, 35). This information presented in total provides the reader a visible comparison of student response in 'interest,' 'need,' and 'competence' categories for the components of direct services, consultation, program development, supervision, teaching, and research that comprise objective $A$. 
OBJECTIVE A: SUPPORTING QUESTIONS SUMMARY

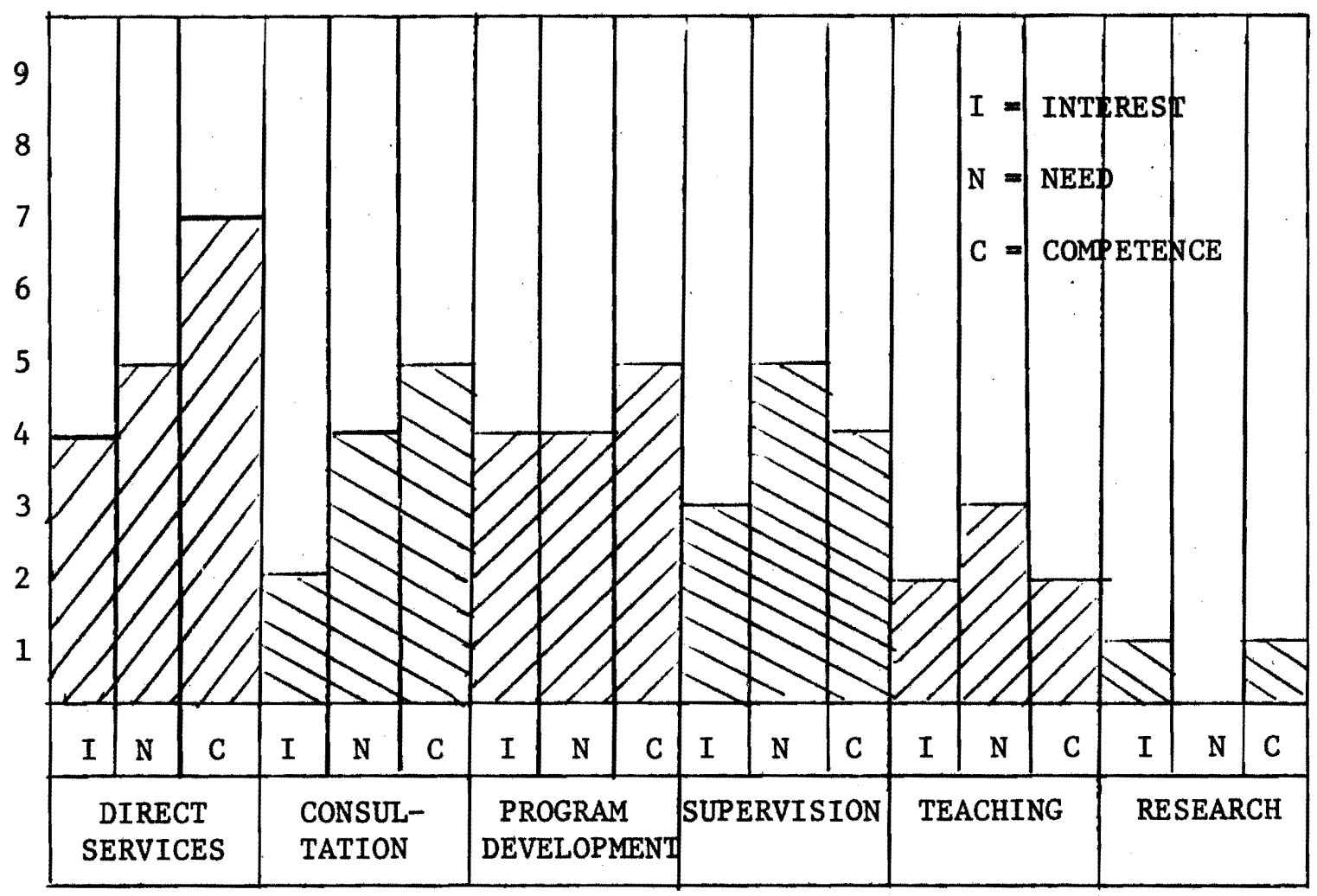

B. To provide instruction to graduate students through various methcids which include individual and group conferences, tape recordings of group and individual contact with clients, process recordings, modeling field instructor, agency personnel, and other social work students at John Adams High School.

OBJECTIVE B

\begin{tabular}{|c|c|c|c|c|c|c|}
\hline ITEM & $\mathrm{N}$ & ONB & LB & B & EB & $\mathrm{N}$ \\
\hline $\begin{array}{l}\text { I. INDIVIDUAL } \\
\text { CONFERENCES }\end{array}$ & 9 & & & 44.44 & 55.56 & \\
\hline
\end{tabular}

When asked to respond to the question "were you provided this type of instruction?", nine students answered affirmatively. of 
these nine students $44.44 \%$ felt these conferences to be 'beneficial,' and $55.56 \%$ felt they were 'extremely beneficial.'

OBJECTIVE B

\begin{tabular}{l|c|c|c|c|c|c|}
\hline ITEM & N & ONB & LB & B & EB & N \\
\hline II. GROUP \\
CONFERENCES & 8 & 12.50 & & 62.50 & 25.00 & \\
\hline
\end{tabular}

Eight students felt they were provided instruction through group conferences. In the category 'of no benefit' there were $12.50 \%$ of the students. The 'beneficial' category reflected $62.50 \%$, while $25.00 \%$ were in the 'extremely beneficial' category.

\section{OBJECTIVE B}

\begin{tabular}{|c|c|c|c|c|c|c|c|}
\hline ITEM & & $\mathrm{N}$ & ONB & LB & B & EB & $\mathrm{N}$ \\
\hline III. & $\begin{array}{l}\text { TAPE } \\
\text { RECORDINGS }\end{array}$ & 8 & & & 62.50 & 37.50 & \\
\hline
\end{tabular}

This item was endorsed affirmatively by eight of the students, indicating they experienced this method of instruction. of these eight students, $62.50 \%$ found the experience to be 'beneficial,' while $37.50 \%$ responded in the 'extremely beneficial' category. 
OBJECTIVE B

\begin{tabular}{l|c|c|c|c|c|c|}
\hline ITEM & N & ONB & LB & B & EB & N \\
\hline IV. PROCESS \\
RECORDINGS & 5 & 20.00 & 20.00 & 60.00 & & \\
\hline
\end{tabular}

Process recordings were felt to have been provided to five students. Both the categories 'of no benefit' and 'lacking benefit' reflected $20.00 \%$ each of the student response. The 'beneficial' category showed the remaining $60.00 \%$.

OBJECTIVE B

\begin{tabular}{|c|c|c|c|c|c|c|}
\hline ITEM & $\mathrm{N}$ & ONB & LB & B & EB & $\mathrm{N}$ \\
\hline $\begin{array}{ll}\text { V. } & \text { MODELING } \\
\text { PERSONNEL }\end{array}$ & 6 & & & 66.67 & 33.33 & \\
\hline
\end{tabular}

When asked to respond to the question "were you provided instruction through modeling of field instructor, agency personnel and other graduate social work students at John Adams High School?", six students replied affirmatively. of these students $66.67 \%$ responded in the 'beneficial' category and $33.33 \%$ in the 'extremely beneficial' category. 


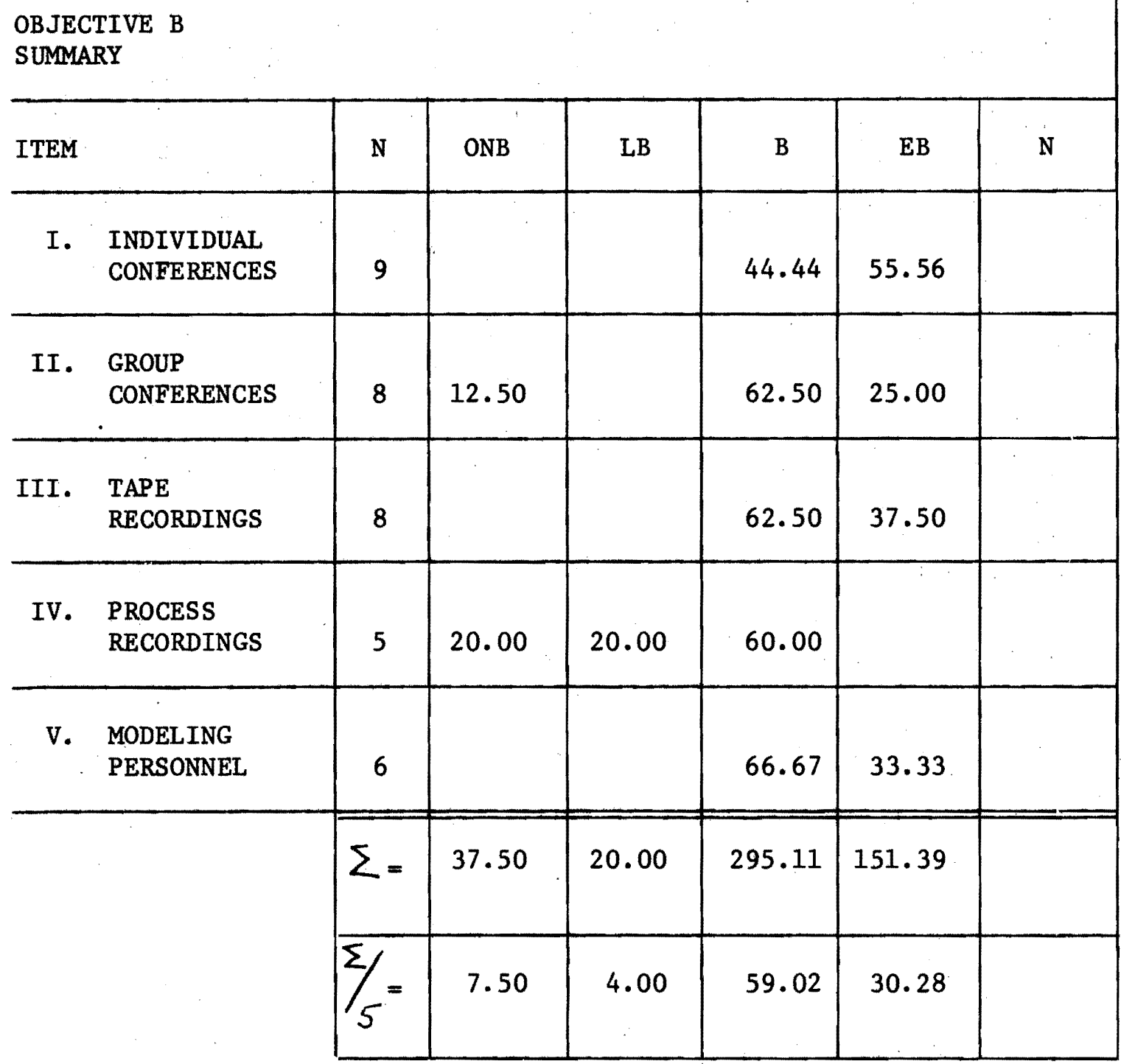

Looking at the total averages of the five items comprising objective $B$, the responses indicate that $7.50 \%$ students found the objective to be 'of no benefit,' $4.00 \%$ 'lacking benefit,' $59.02 \%$ 'beneficial,' and $30.28 \%$ 'extremely beneficial.' 
C. To acquaint students with other resources in the community and how to utilize them in their performance as a school social worker.

\section{OBJECTIVE C}

\begin{tabular}{|c|c|c|c|c|c|c|}
\hline ITEM & $\mathrm{N}$ & ONB & LB & B & EB & N \\
\hline $\begin{array}{ll}\text { I. } & \text { FORMAI } \\
& \text { PRESENTATIONS }\end{array}$ & 4 & & & 75.00 & 25.00 & \\
\hline
\end{tabular}

When asked to respond to the question "were you acquainted with community resources and how they are used through formal presentations by other personnel within the agency?', four students answered affirmatively that they were provided this type of instruction, and five students felt they had not. Of these four students $75.00 \%$ felt these presentations to be 'beneficial,' and $25.00 \%$ felt they were 'extremely beneficial.'

OBJECTIVE C

\begin{tabular}{|c|c|c|c|c|c|c|c|}
\hline ITEM & & $\mathrm{N}$ & ONB & LB & B & EB & $\mathrm{N}$ \\
\hline II. & $\begin{array}{l}\text { FORMAL FIELD } \\
\text { VISITS }\end{array}$ & 7 & & 14.29 & 72.45 & 14.29 & \\
\hline
\end{tabular}

Seven students felt they were acquainted with community resources through formal field visits. Of these seven students $14.29 \%$ felt the field visits to be 'lacking benefit,' $72.45 \%$ felt these visits to be 'beneficial,' and $14.29 \%$ found them 'extremely beneficlal.' 
OBJECTIVE C

\begin{tabular}{l|c|c|c|c|c|c}
\hline ITEM & $\mathrm{N}$ & ONB & LB & $\mathrm{B}$ & $\mathrm{EB}$ & $\mathrm{N}$ \\
\hline III. $\begin{array}{l}\text { REFERRAL } \\
\text { RESOURCES }\end{array}$ & 9 & & & 88.89 & 11.11 & \\
\hline
\end{tabular}

This item was endorsed affirmatively by all nine students indicating they had experiences with clients requiring use of referral agency resources. Of these nine students $88.89 \%$ found these experiences to be 'beneficial,' with $11.11 \%$ finding them 'extremely beneficial.'

OBJECTIVE C

\begin{tabular}{|c|c|c|c|c|c|c|c|}
\hline ITEM & & $\mathbf{N}$ & ONB & LB & B & EB & $\mathrm{N}$ \\
\hline IV. & $\begin{array}{l}\text { STUDENT } \\
\text { INTERACTION }\end{array}$ & 6 & & & 50.01 & 50.01 & \\
\hline
\end{tabular}

"Interaction with other unit students and social workers regarding community resources" was felt to have been provided to six of the nine students. Of these six both the categories of 'beneficial' and 'extremely beneficial' reflected $50.01 \%$ each of the student response. 


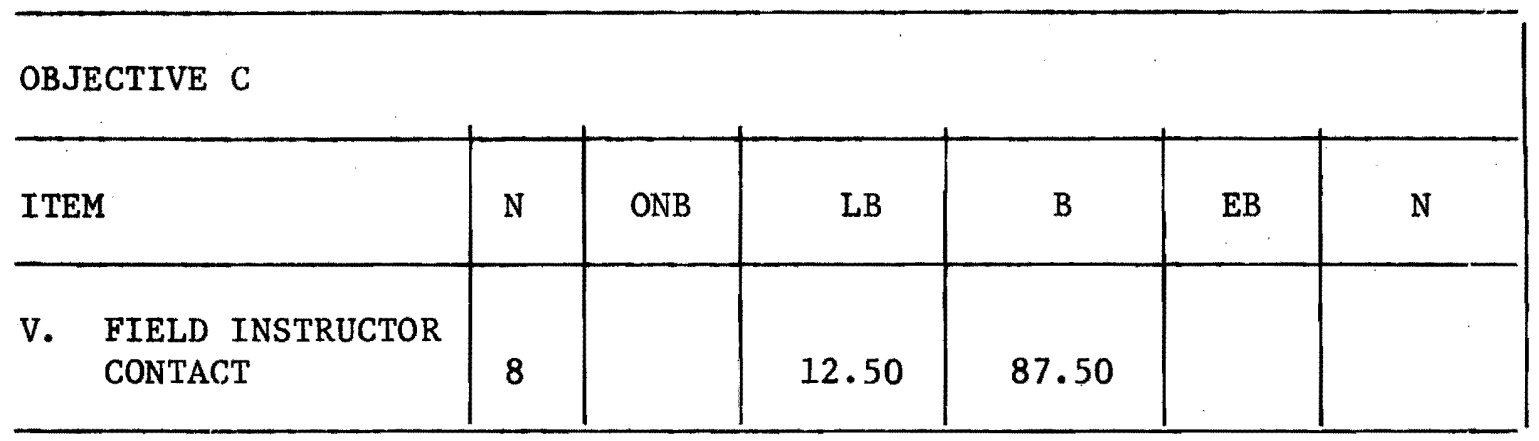

When asked to respond to the question "were you acquainted with community resources through contact with the field instructor?", eight of the nine students responded affirmatively. of these eight students $12.50 \%$ felt the experience to be 'lacking benefit,' while $87.50 \%$ found it to be 'beneficial.' 
OBJECTIVE C
SUMMARY

\begin{tabular}{|c|c|c|c|c|c|c|c|}
\hline ITEM & & $\mathrm{N}$ & ONB & LB & B & EB & $\mathrm{N}$ \\
\hline I. & $\begin{array}{l}\text { FORMAL } \\
\text { PRESENTATIONS }\end{array}$ & 4 & & & 75.00 & 25.00 & \\
\hline II. & $\begin{array}{l}\text { FORMAL FIELD } \\
\text { VISITS }\end{array}$ & 7 & & 14.29 & 72.45 & 14.29 & \\
\hline III. & $\begin{array}{l}\text { REFERRAL } \\
\text { RESOURCES }\end{array}$ & 9 & & & 88.89 & 11.11 & \\
\hline IV. & $\begin{array}{l}\text { STUDENT } \\
\text { INTERACTION }\end{array}$ & 6 & & & 50.01 & 50.01 & \\
\hline v. & $\begin{array}{l}\text { FIELD INSTRUC- } \\
\text { TOR CONTACT }\end{array}$ & 8 & & 12.50 & 87.50 & & \\
\hline & & $\Sigma=$ & & 26.79 & 373.85 & 100.41 & \\
\hline & & 51 & & 5.36 & 74.77 & 20.08 & \\
\hline
\end{tabular}

Looking at the total averages of the five items comprising obfective $\mathrm{C}$, the responses indicated that $5.36 \%$ of the students found the objective to be 'lacking benefit,' $74.77 \%$ 'beneficlal,' and $20.08 \%$ 'extremely beneficial.' 
D. To help students gain a better awareness of their self and how this understanding affects their performance as a social worker.

OBJECTIVE D

\begin{tabular}{|l|l|l|l|l|l|c|}
\hline ITEM & $\mathrm{N}$ & ONB & LB & B & EB & $N$ \\
\hline I. CONFERENCES & 8 & & & 37.50 & 50.00 & 12.50 \\
\hline
\end{tabular}

When asked "did you gain self awareness through conferences with field instructor?", eight of the nine students responded affirmatively. of these eight students $37.50 \%$ felt these conferences to be 'beneficial,' while $50.00 \%$ felt they were 'extremely beneficial.' The 'neutral' category elicited $12.50 \%$ of the responses.

OBJECTIVE D

\begin{tabular}{|l|l|l|l|l|l|l|}
\hline ITEM & N & ONB & LB & B & EB & N \\
\hline II. $\begin{array}{l}\text { CLIENT } \\
\text { CONTACT }\end{array}$ & 9 & & & 55.56 & 44.44 & \\
\hline
\end{tabular}

Nine students felt they gained self awareness through "experiences with clients and other social work experiences in the agency." of these students $55.56 \%$ felt the experiences to be 'beneficial,' with $44.44 \%$ responding in the 'extremely beneficial' category. 
OBJECTIVE D

\begin{tabular}{|l|l|l|l|l|l|l|}
\hline ITEM & N & ONB & LB & B & EB & N \\
\hline III. READINGS & 4 & & & 50.00 & 50.00 & \\
\hline
\end{tabular}

Four of the nine students felt they gained self awareness through "readings provided in the field." Both the categories 'beneficial! and 'extremely beneficial' each recelved $50.00 \%$ of the student responses.

OBJECTIVE D

\begin{tabular}{|l|l|l|l|l|l|l|}
\hline ITEM & $\mathrm{N}$ & ONB & LB & B & EB & $N$ \\
\hline IV. PEER INTERACTION & 6 & & & 33.33 & 66.67 & \\
\hline
\end{tabular}

The item "did you gain self awareness through interaction with peers?" was endorsed affirmatively by six of the nine students. The category 'beneficlal' reflected $33.33 \%$ of the student response, with 'extremely beneficial' reflecting the remaining $66.67 \%$.

OBJECTIVE D

\begin{tabular}{|c|c|c|c|c|c|c|}
\hline ITEM & $\mathrm{N}$ & ONB & LB & B & EB & $\mathrm{N}$ \\
\hline $\begin{array}{ll}\text { V. FORMAL } \\
\text { PRESENTATIONS }\end{array}$ & 6 & & & 83.35 & 16.67 & \\
\hline
\end{tabular}


Six of the nine students felt they gained self awareness through

"formal presentations by field instructor and other instruction or speakers." of these six students $83.35 \%$ felt the experience to be 'beneficial' while $16.67 \%$ felt it to be 'extremely beneficial.'

OBJECTIVE D

SUMMARY

\begin{tabular}{|c|c|c|c|c|c|c|c|}
\hline ITEM & & $\mathrm{N}$ & ONB & LB & B & EB & $\mathrm{N}$ \\
\hline I. & CONFERENCES & 8 & & & 37.50 & 50.00 & 12.50 \\
\hline II. & $\begin{array}{l}\text { CLIENT } \\
\text { CONTACT }\end{array}$ & 9 & & & 55.56 & 44.44 & \\
\hline III. & READINGS & 4 & & & 50.00 & 50.00 & \\
\hline IV. & $\begin{array}{l}\text { PEER } \\
\text { INTERACTION }\end{array}$ & 6 & & & 33.33 & 66.67 & \\
\hline V. & $\begin{array}{l}\text { FORMAL } \\
\text { PRESENTATIONS }\end{array}$ & 6 & & & 83.35 & 16.67 & \\
\hline & & $\Sigma=$ & & & 259.74 & 227.78 & 12.50 \\
\hline & & 5 & & ! & 51.95 & 45.56 & 2.50 \\
\hline
\end{tabular}


Looking at the total averages of the five items comprising objective $D$, the responses indicated that $51.95 \%$ of the students felt the objective to be 'beneficial,' $45.56 \%$ 'extremely beneficial,' with $2.50 \%$ in the 'neutral' category.

E. To provide training experiences for students in working with minority groups.

OBJECTIVE E

\begin{tabular}{|l|c|c|c|c|c|c|}
\hline ITEM & N & ONB & LB & B & EB & $N$ \\
\hline I. MINORITY \\
CLIENTS & 8 & & & 50.00 & 50.00 & \\
\hline
\end{tabular}

When asked to respond to the question "were you provided training experiences working with minority groups through contact with minority clients," eight of the nine students responded affirmatively. For these eight students the categories 'beneficial' and 'extremely beneficial' each reflected $50.00 \%$ of the response.

OBJECTIVE E

\begin{tabular}{l|c|c|c|c|c|c|}
\hline ITEM & N & ONB & LB & B & EB & N \\
\hline II. $\begin{array}{c}\text { MINORITY } \\
\text { PERSONNEL }\end{array}$ & 7 & & & & & \\
\hline
\end{tabular}

Seven of the nine students felt they were provided training experiences through "contact with minority teachers or other minority 
schoo1 personne1." of these seven students $42.87 \%$ felt the experiences to be 'beneficial,' with $57.16 \%$ responding in the 'extremely beneficial' category.

OBJECTIVE E

$\left.\begin{array}{|l|l|l|l|l|l|l|}\hline \text { ITEM } & \mathrm{N} & \text { ONB } & \text { LB } & \text { B } & \text { EB } & \text { N } \\ \hline \text { III. MINORITY GRADU- } \\ \text { ATE STUDENTS }\end{array}\right)$

This item was endorsed affirmatively by seven of the nine students indicating they were provided training experiences working with minority groups through "interaction or relationships with fellow unit minority students." of these seven students $14.29 \%$ found these experiences to be 'beneficial,' with $85.74 \%$ finding them 'extremely beneficial.'

OBJECTIVE E

\begin{tabular}{l|l|l|l|l|l|l}
\hline ITEM & $\mathrm{N}$ & ONB & LB & B & EB & N \\
\hline IV. READINGS & 7 & 14.29 & & 72.29 & 14.29 & \\
\hline
\end{tabular}

"Readings concerning minority groups or problems" were felt to have been provided to seven of the nine students. The categories reflected $14.29 \%$ 'of no benefit,' $72.45 \%$ 'beneficial,' and $14.29 \%$ 'extremely beneficial.' 
OBJECTIVE E

\begin{tabular}{l|l|l|l|l|l|l|}
\hline ITEM & $\mathrm{N}$ & ONB & LB & B & EB & N \\
\hline V. INSTRUCTION & 6 & & 16.67 & 33.33 & 50.00 & \\
\hline
\end{tabular}

Six of the nine students felt they were provided "instruction in minority issues by field instructor or other personnel . . ." The categories reflected $16.67 \%$ 'lacking benefit,' $33.33 \%$ 'beneficial,' and $50.00 \%$ 'extremely beneficial.' 
OBJECTIVE E SUMMARY

\begin{tabular}{|c|c|c|c|c|c|c|c|}
\hline ITEM & & $\mathrm{N}$ & ONB & LB & B & EB & $\mathrm{N}$ \\
\hline I. & $\begin{array}{l}\text { MINORITY } \\
\text { CLIENTS }\end{array}$ & 8 & & & 50.00 & 50.00 & \\
\hline II. & $\begin{array}{l}\text { MINORITY } \\
\text { PERSONNEL }\end{array}$ & 7 & & & 42.87 & 57.16 & \\
\hline III. & $\begin{array}{l}\text { MINORITY GRADU- } \\
\text { ATE STUDENTS }\end{array}$ & 7 & & & 14.29 & 85.74 & \\
\hline IV. & READINGS & 7 & 14.29 & & 72.45 & 14.29 & \\
\hline v. & INSTRUCTION & 6 & & 16.67 & 33.33 & 50.00 & \\
\hline & & $\Sigma=$ & 14.29 & 16.67 & 212.94 & 257.19 & \\
\hline & & $z /=$ & 2.86 & 3.33 & 52.60 & 51.44 & \\
\hline
\end{tabular}

Looking at the total averages of the five items comprising this objective the responses indicated that $2.86 \%$ of the students found the objective to be 'of no benefit,' $3.33 \%$ 'lacking benefit,' $42.60 \%$ 'beneficial,' and $51.44 \%$ 'extremely beneficial.' 
F. To expose students to the vital areas of John Adams High School in an effort to determine the effectiveness of that area for the performance of a school social worker.

OBJECTIVE F

\begin{tabular}{l|l|l|l|l|l|l}
\hline ITEM & N & ONB & LB & B & EB & N \\
\hline $\begin{array}{l}\text { I. GENERAL EDUCA- } \\
\text { TION TEAMS }\end{array}$ & 8 & 25.00 & 37.50 & & 37.50 & \\
\hline
\end{tabular}

When asked to respond to the question "did you work with general education teams?", eight out of nine students answered affirmatively. of these eight students $25.00 \%$ felt this experience to be 'beneficial,' $37.50 \%$ 'lacking benefit,' and $37.50 \%$ 'extremely beneficial.' Five of these eight students indicated they would recommend this area for continued use in training graduate students in school social work.

OBJECTIVE F

\begin{tabular}{l|l|l|l|l|l|l|}
\hline ITEM & N & ONB & LB & B & EB & N \\
\hline II. $\begin{array}{l}\text { SCHOOL ADMINIS- } \\
\text { TRATORS }\end{array}$ & 4 & & & & & \\
\hline
\end{tabular}

Four of the nine students indicated that they worked with school administrators. The 'beneficial' category reflected $25.00 \%$ of the responses, 'extremely beneficial' reflected $50.00 \%$, and the 'neutral' category reflected the remaining $25.00 \%$. of these four students three would recommend this area for continued use in training graduate students in school social work. 
OBJECTIVE F

\begin{tabular}{l|l|l|l|l|l|l|}
\hline ITEM & N & ONB & LB & B & EB & N \\
\hline III. SCHOOL \\
COUNSELORS & 8 & & & 87.50 & 12.50 & \\
\hline
\end{tabular}

This item was endorsed affirmatively by eight of the nine studerits indicating that they had worked with school counselors. Of these eight students $87.50 \%$ found this experience to be 'beneficial,' with $12.50 \%$ finding it 'extremely beneficial.' All of these students would recommend this area for continued use in training graduate students in school social work.

OBJECTIVE F

\begin{tabular}{l|c|c|c|c|c|c|}
\hline ITEM & N & ONB & LB & B & EB & N \\
\hline IV. SCHOOL SOCIAL \\
WORKER
\end{tabular}

"Did you work with school social worker?" was answered affirmatively by eight of the nine students. The categories reflected $12.50 \%$ ' 1 acking benefit,' $50.00 \%$ 'beneficial,' and $37.50 \%$ 'extremely beneficial.' Seven of these eight students would recommend this area for continued use in training graduate students in school social work. 
OBJECTIVE F

\begin{tabular}{l|c|c|c|c|c|c|}
\hline ITEM & N & ONB & LB & B & EB & N \\
\hline V. $\begin{array}{l}\text { RESEARCH } \\
\text { DEPARTMENT }\end{array}$ & 2 & & & & & \\
\hline
\end{tabular}

Two of the nine students indicated that they had worked with the research department. Both the categories 'extremely beneficial' and 'neutral' reflected $50.00 \%$ each of the responses. Of these two students one would recommend this area for continued use in training graduate students in school social work. 
OBJECTIVE F SUMMARY

\begin{tabular}{|c|c|c|c|c|c|c|c|}
\hline ITEM & & $\mathrm{N}$ & ONB & LB & B & EB & $\mathrm{N}$ \\
\hline I. & $\begin{array}{l}\text { GENERAL EDUCA- } \\
\text { TION TEAMS }\end{array}$ & 8 & 25.00 & 37.50 & & 37.50 & \\
\hline II. & $\begin{array}{l}\text { SCHOOL ADMINIS- } \\
\text { TRATORS }\end{array}$ & 4 & & & 25.00 & 50.00 & 25.00 \\
\hline III. & $\begin{array}{l}\text { SCHOOL } \\
\text { COUNSELORS }\end{array}$ & 8 & & & 87.50 & 12.50 & \\
\hline IV. & $\begin{array}{l}\text { SCHOOL SOCIAL } \\
\text { WORKER }\end{array}$ & 8 & & 12.50 & 50.00 & 37.50 & \\
\hline V. & $\begin{array}{l}\text { RESEARCH } \\
\text { DEPARTMENT }\end{array}$ & 2 & & & & 50.00 & 50.00 \\
\hline & & $\Sigma=$ & 25.00 & 50.00 & 162.50 & 187.50 & 75.00 \\
\hline & & $\Sigma /=$ & 5.00 & 10.00 & 32.50 & 37.50 & 15.00 \\
\hline
\end{tabular}

Looking at the total averages of the five items comprising objective $\mathrm{F}$, the responses indicated that $5.00 \%$ of the students found the objective to be 'of no benefit,' $10.00 \%$ 'lacking benefit, $32.50 \%$ 'beneficial,' $37.50 \%$ 'extremely beneficial,' and $15.00 \%$ 'neutral.' 
OBJECTIVES A through $\mathrm{F}$ TOTAL SUMMARY

\begin{tabular}{|c|c|c|c|c|c|c|}
\hline OBJECTIVES & $\operatorname{Tr}$ & ONB & LB & B & $\mathrm{EB}$ & $\mathrm{N}$ \\
\hline A. & 16 & & 8.75 & 44.19 & 43.07 & 3.99 \\
\hline B. & 5 & 7.50 & 4.00 & 59.02 & 30.28 & \\
\hline C. & 5 & & 5.36 & 74.77 & 20.08 & \\
\hline D. & 5 & & & 51.95 & 45.56 & 2.50 \\
\hline E. & 5 & 2.86 & 3.33 & 42.60 & 51.44 & \\
\hline \multirow[t]{3}{*}{ F. } & 5 & 5.00 & 10.00 & 32.50 & 37.50 & 15.00 \\
\hline & $\Sigma=$ & 15.36 & 31.44 & 305.03 & 227.93 & 21.49 \\
\hline & $6=$ & 2.56 & 5.24 & 50.84 & 37.99 & 3.58 \\
\hline
\end{tabular}

Looking at the entire instrument comprised of objectives $A-F$ the total average responses of the students are $2.56 \%$ 'of no benefit,' $5.24 \%$ '1acking benefit,' $50.84 \%$ 'beneficial,' $37.99 \%$ 'extremely beneficial' and $3.58 \%$ 'neutral.' 


\section{CHAPTER VIII}

\section{SUMMARY AND CONCLUSIONS}

This study was undertaken in an attempt to answer three basic questions: 1) Can a graduate school social work field instruction unit in public school social work on the elementary and secondary levels be evaluated? 2) If it can be evaluated, can an ongoing instrument be developed allowing for program and Individual and student evaluation? 3) Can the study provide data for the program director's evaluation of the effectiveness of his training? The population sample of this study was too small for statistical inference, but in reference to the above goal number one we feel that we did subjectively evaluate the program, therefore concluding that the program can indeed be evaluated. In response to goal number two we feel the instrument can be used as an ongoing evaluation tool, as will be discussed in the next section. We conclude that the instrument does not provide statistical evidence of success or fallure of the program goals and objectives but rather provides limited data allowing for subjective interpretation by the field instructor as prescribed in goal number three.

In closing we feel the following recommendations will be of some assistance to those individuals working to make use of this study or those wishing to continue the program evaluation in the future. We feel that this research is a pioneer study as evidenced by the total lack of resources avallable through the research of the 
11terature. Both a manual and computer search was performed through the Retrieval-Dissemination Center of the Oregon Board of Education (ERIC). (See appendix number 2)

With the baseline data provided by this study there are several issues to be considered if one desires to interpret or continue the study .

1. The validity and results of the instrument can be tested by using the same questionnalre over a three-year period of time, thereby providing information regarding frequency and percentage of change within the operation of the Adams training program. Analysis of these changes and their direction document favorable or unfavorable trends within the program.

2. New students can refine the instrument to obtain more specific information derived from our study.

3. Even though certain portions of our instrument will remain valid, as the program changes various aspects of the instrument could or might have to be changed. Those portions of our study that remain intack in future instruments will provide comparative information that could show trend or percentage changes in the program.

4. We found the question dealing with 'the number of experiences for any particular educative item' not of particular use or importance for this evaluation so it was therefore eliminated.

5. This instrument is an attitude scale given at a specific time for a specific purpose. Interpretation of success or 
failure of the program cannot be statistically founded;

however, interpretation of success or fallure can rest with the program director.

6. Finally, we feel this research can be of assistance in future summary progress reports issued to the funding agency. We also recommend this evaluation and any following be Included in the grant funding proposals. 


\section{A SELECTED BIBLIOGRAPHY}

Arbit, Sandra D. "Working with Parents." Social Work, July 1956.

Borko, Harold and Mathies, Lorraine, eds. "All About Eric." Journal of Educational Data Processing, Vol. 7, No. 2, April 1970.

Easley, et al. Evaluation of the Role of Neighborhood Health Coordinators, (RESEARCH THESIS), 1969.

Falrweather, George W. Methods for Experimental Social Innovation. John Wiley and Sons, Inc., New York, 1964.

Herzog, Elizabeth. Some Guidelines for Evaluative Research. U.S. Department of Health, Education, and Welfare, Children's Bureau Publication No. 375. U.S. Government Printing office, Washington, D.C., 1959 , p. 12 .

Jones, Milton 0. "Inservice Training for Student Personnel Workers - . A Practicum Approach at Clearwater Campus," 1970. (ERIC) (A speech delivered at the American College Personnel Association 1970 Conference, St. Louis, Mo., March 16, 1970.)

Klineberg, Otto. "The Problam of Evaluation." International Social Science Bulletin, VII, No. 3, 1955, p. 346.

Lawrence, Richard G. and Brown, George Warren. The Use of Research Results in Teaching Social Work Practice. School of Social Work, Washington University, January 1967.

"0ld Problems and New Proposals." Field Instruction In Graduate School Work Education, Counc1l on Social Work Education, New York, 1966.

Oppenheim, A.N. Questionnaire Design and Attitude Measurement. Basic Books, Inc., New York, 1966.

"Profile of a High School." Ph1 Delta Kappan, May 1971, pp. 514-527. "Profile of a High School: Introduction," Robert B. Schwartz; "Instruction at Adams," Allen L. Dobbins; "Teacher Training at Adams," John L. Parker; "Research and Evaluation at Adams," Jerry L. Fletcher; "School Climate and Student Learning," Patricia A. Wertheimer.

The School as a Setting for Soctal Work Services. Special Education Institute Series, February 6-10, 1967, State of Iowa, Des Moines, Iowa, 1967. 
Sheps, Cecil G. and Madison, Donald L. Evaluation of Ne1ghborhood Health Centers--A Plan for Implementation. Report to the Office of Economic Opportunity, Washington, D.C., July 1967. Mount Sinal Medical School, New York, 1967, p. 1.

Staples, Richard M., ed. School Social Work. A description of school social work guidelines for a school social work program, Department of Public Instruction, State of Wisconsin, Bulletin 149, November 1967.

Suchman, Edward A. Evaluative Research. Russell Sage Foundation, New York, 1967, p. 75.

Suchman, Edward A. "Principles and Practice of Evaluative Research." An Introduction to Social Research. John Doby, ed., AppletonCentury-Crofts, New York, 1967, p. 329.

Weinberg, George H. and Schumaker, John A. Statistics An Intuitive Approach, Second Edition. Brooks/Cole Publishing Company, Belmont, California, 1969. 
APPENDIX NUMBER 1

PRETEST CHECKLIST QUESTIONNAIRE 


\section{JOHN ADAMS SOCIAL WORK UNIT}

Evaluation

I. Robert Roy, Unit Field Supervisor, has listed the following goal and objectives as the basis of the social work field experience at John Adams High School. Do you agree that these are pertinent (not necessarily practiced) to your field education?

A. Do you agree that the following objectives are important to your social work field education? (Check YES or NO).

Goal: To provide graduate social work students a training experience in social work that meets the needs and interests of the individual student. This will be accomplished through "school social work" in elementary (1-8) and secondary educational settings.

RANK YES NO Objectives:

a. To provide training experiences in direct service, consultation, program development, supervision, teaching, and research.

b. To provide instruction to graduate students through various methods; which include individual and group conferences, presentation of theoretical material, tape recordings of student experiences, process recordings, modeling and joint participation experiences.

c. To acquaint students with educational systems and how they relate to the functioning of a school social worker.

d. To acquaint students with other resources in the community and how to utilize them in their performance as a school social worker.

e. To help students gain a better awareness of their self and how this understanding affects their performance as a social worker.

f. To provide training experiences for students in working with minority groups.

g. To provide an awareness of John Adams High School functioning as compared to other more traditional high schools. 
h. To provide the opportunity to explore the different modes of functioning of school social workers at Adams High School as compared to other more traditional high schools.

i. To coordinate the material presented in the classroom with training experiences in the field unit.

f. To expose students to the vital areas of John Adams High School in an effort to determine the effectiveness of that area for the performance of a school social worker.

II. Are there any other objectives not listed above that you feel are relevant to your field instruction at John Adams High School?

RANK

- k.

1 .

m.

n.

III. Please rank in order of importance (numerically) those listed objectives you agreed with plus any additions. 
APPENDIX NUMBER 2

EDUCATION RETRIEVAL-DISSEMINATION CENTER RESULTS 


\title{
RESOURCE DISSEMINATION \\ CEN TER
}

\author{
Oregon Board of Education \\ 942 Lancaster Drive, NE \\ Salem, Oregon 97310
}

\section{RESOURCE INFORMATION} FOR QUALITY EDUCATION

This Material Was Prepared For

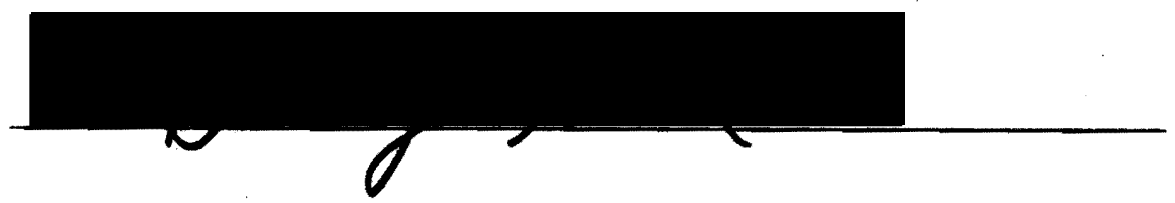


OREGON BOARD OF EDUCATION

RETRIEVAL-DISSEMINATION CENTER

942 Lancaster Drive N.E., Salem, Oregon 97310

Telephone 378-3566

HOW TO USE AN ABSTRACT

Please read the definitions below and examine the format of the abstract before beginning work on your packet.

ED - NUMBER: This is a number that is assigned to each ERIC document abstracted and is used for identification and ordering documents and microfiche. It is referred to as the ED number. It is located at the upper left corner of each abstract.

ABSTRACT: An abstract is a factual, objective, abbreviated version of a complete document. The term document is used to describe any published materials such as research reports, dissertations, bibliographies or monographs. Most ERIC abstracts not only highlight the contents of a document, but also provide a succinct summary of the purposes, procedures and findings of the original document. Most ERIC documents are available on microfiche.

PUBLISHER: An alternative source to obtain the document if not available from EDRS Eric Document Reproduction Service.

DESCRIPTORS: These are educational keywords assigned from the ERIC Thesaurus and are used as a basis for the computer logic which retrieves research information. Scanning these w11l offer synonyms for your future searching.

\section{NOTES ON MICROFICHE}

Microfiche (MF) of ERIC documents may be viewed at:

-CASEA (Center for the Advanced Study of Educational Administration), 1472 Kincaid Street, Eugene, Oregon 686-5174

-Northwest Regional Educational Laboratory, Portland, Oregon 224-3650

-Oregon State University Library, Corvallis, Oregon 754-3331

-Portland State University Library, Portland, Oregon 229-3684

-Retrieval-Dissemination Center, Salem, Oregon 378-3566

Microfiche may be checked out through your school librarian from:

-Oregon State Library, Capitol Mall, Salem, Oregon 378-4276

-Southern Oregon College Library, Ashland, Oregon 482-6445

Hard copy (HC) of ERIC documents may be obtained from the above sources (except the Retrieval-Dissemination Center), for approximately $10 \mathrm{c}$ per page or ordered directly from: ERIC Document Reproduction Service, LEASCO Information Products, Inc., P.0. Drawer 0, Bethesda, Maryland 20014. Please indicate the ED Number of the document desired. HC costs are given on your abstracts.

Those documents marked (not available from EDRS) may be obtained through normal library channels or ordered directly from the publisher. 
OREGON BOARD OF EDUCATION RETRIEVAL-DISSEMINATION CENTER

942 Lancaster Drive NE, Salem, Oregon 97310

RETRIEVAL-DISSEMINATION REPORT

Name George Hal1 (send c/o Don Barr,

School of Social Work (PSU)

72-1449

Dissemination Project No.

Title

Phone No: 297-2095 Schoo1: John Adams

\begin{tabular}{lccc}
5700 N.E. 39th Ave. / Portland & $/$ Multnomah & $/ 97211$ \\
\hline Street Address & City & County & Zip
\end{tabular}

1. Date of Request application $4 \times 72$

2. Date submitted to Retrieval Staff $4 \times 72$. How? Phone X letter

3. Did the request come directly from the requester? Yes $\mathrm{X}$ No

4. Description of information requested: Identify evaluation studies

of field training programs for school social workers

St.

5. Submitted to Referral Source: ERIC Otis OBE Other SourceLibrary

6. Date of submission to Referral Source 10-5-72

7. Date Information returned to Retrieval Staff $17 \times 72$

8. Date information passed on to area resource specialist $24 \times 72$

9. Other actions taken: (Consultants, State Library, etc.) Manual search of RIE, Ed Index, Letter to Counc1l on Soc1a1 Work Education, Called Claude Morgan, OBE counseling specialist 
ACCESSICN NUMBER: EDO42449

PUBLICATION DATE: 70

TITLE: IN-SERVICE TRAINING FCR STUDENT PERSONNEL WORKERS--A PRACT ICUM APPROACH AT CLEARWATER CAMPUS.

PERSONAL AUTHOR: JUNES, MILTCN C.

DESCRIPTOR: \#COUNSELING SERVICES; COUNSELORS; *COUNSELCR TRAINING: *INSERVICE PROGRAMS: *JUNIOR COLLEGES; PRACTICUMS: PROFESSICNAL IRAINING: STUDENT PERSCNNEL SERVICES: STUDENT PERSCNNEL WORKERS

\section{IDENTIFIER: $\quad$ *FLORICA}

EDRS PRICE: ECRS PRICE MF-\$0.25 HC NCT AVAILABLE FRCM ECRS.

DESCRIPTIVF NOTE: 5P.: SPEECH DELIVERED AT THE AMERICAN COLLEGE PERSCNNEL ASSOCIATICN 1970 CONFERENCE, ST. LOUIS. MISSOURI, MARCH 16, LS70

THE STUDENI PERSONNEL STAFF AT ST. PETERSBURG JUNIOR COLLEGE, CLEARWATER CAMPUS, PARTICIPATED IN SEVERAL IN-SERVICE TRAINING SEMINARS TC UP-DATE AND IMPRCVE PROCEDURFS AND TECHNIOUES FOR DEALING WITH INDIVICUAL STUDENTS - A CCNSULTANT FROM THE UNIVERSITY OF FLORIDA, AND THE ST. PETERSEURG JUNICR COLLEGE DEAN OF STUDENT PERSONAEL CONDUCTEC THE SEMINARS. RECENT ADVANCES IN CCUNSELING THEORY AND RESEARCH WERE DISCLSSED AND CRITIQUES CF TAPED COUNSEL ING SESSIONS WERE CONDUCTED. MOST PARTICIPANTS FELT THE PROGRAM HAC POSITIVE RESULTS, ESPECIALLY IN THE AREAS CF SELF-EVALUATION AND TECHNIQUE IMPFOVEMENT. - BECAUSE CF MARGINAL REPRODUCIBILITY OF ORIGINAL. THIS DOCUMENT IS NCT AVAILABLE IN HARC COPY.' (JO) 
APPENDIX NUMBER 3

QUESTIONNAIRE 


\section{INTRODUCTION}

The following questionnaire is an attempt to answer two basic questions:

1. Can a graduate school social work field instruction unit in public school social work on the elementary and secondary levels be evaluated?

2. If it can be evaluated, can an ongoing instrument be developed allowing for program and individual student evaluation?

Your name need not be signed to the questionnaire; your individual responses will be anonymous. Our only concern is with patterns projected by the combined responses of all participants.

The questionnaire is designed to study the functioning of the entire social work unit, rather than the performance of individuals within the unit. 


\title{
JCHN ADAMS SOCIAL WORK UNIT
}

\author{
Evaluation
}

Robert Roy, Unit Fleld Supervisor, has listed the following goal and objectives as the basis of the social work field experience at John Adams High School

Goal: To provide graduate social work students a training experience in social work that meets the needs and interests of the individual student. This will be accomplished through "School Social Work" in elementary (1-8) and secondary educational settings.

\section{Objectives:}

a. To provide training experiences in direct service, consultation, program development, supervision, teaching, and research.

b. To provide instruction to graduate students through various methods; which include individual and group conferences; tape recordings of group and individual contact with clients; process recordings; modeling field instructor, agency personnel, and other social work students at John Adams High School.

c. To acquaint students with other resources in the community and how to utilize them in their performance as a school social worker.

d. To help students gain a better awareness of their self and how this understanding affects their performance as a social worker.

e. To provide training experiences for students in working with minority groups.

f. To expose students to the vital areas of John Adams High School in an effort to determine the effectiveness of that area for the performance of a school social worker. 


\section{GENERAL INSTRUCTIONS}

1. All questions must be answered according to the specific instructions presented.

2. There are four different sections.

3. There is no time limit for completing the questionnaire so plesse read and answer each question carefully and thoughtfully.

4. If you have any questions while completing the questionnaire, raise your hand for assistance.

5. Please mark all your responses on the answer sheet provided. If you change an answer, please erase your previous response completely. It is important that only one response is given for each question.

6. The numbers on the questionnaire correspond to the same numbers on the answer sheet. 


\section{PART I: Section I}

CBJECTIVE A: TO PROVIDE TRAINING EXPERIENCE IN DIRECT SERVICES, CONSULTATION, PROGRAM DEVELOPMENT, SUPERVISION, TEACHING, AND RESEARCH.

In direct services were you provided:

1. Assignments that provided service to children and families? (If your answer was NO go on to \#4)

2. If your response was YES to the above, please mark the category representing the number of experiences you had for the

total year..........................
$0-3$
$\frac{4-7}{b}$
8-11
a
$-7 \quad 8-1$
12-or over
d

3. If you responded to the above, how beneficial was this experience in of no lacking beneficial extremely benefit benefit beneficial

neutral furthering your social work education?

\begin{tabular}{llll}
\hline & 3 & 4 & 5
\end{tabular}

In direct services were you provided:

4. Assignments that provided social work treatment to children and families? (If your response was No go on to \#7)

5. If your response was YES to the above, please mark the category representing the number of experiences you had for the total year....................

6. If you responded to the above, how beneficial was this experience in furthering your social work education?

$\begin{array}{cccc}0-3 & 4-7 & 8-11 & 12-\text { or over } \\ a & b & c & d\end{array}$

\begin{tabular}{lll} 
of no lacking beneficial & $\begin{array}{l}\text { extremely neutral } \\
\text { beneficial }\end{array}$ \\
\hline
\end{tabular}

12345

(1) 
In direct services were you provided:

7. Assignments that provided work with clients in groups?

(If your response was NO go on to \#10)

8. If your response was YaS to the above, please mark the category representing the number of experiences you had for the total

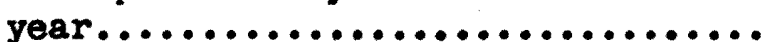

$$
0-3
$$

of no benefit
$4-7$

$\mathrm{b}$

lacking

benefit
$8-11$

c

beneficial

beneficial was this experience in

furthering your social work education?

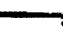

\section{2}

12-or over d

extremely beneficial

neutra1

4

In direct services were you provided:

10. Assignments that provide experience in diagnosis and treatment?

(If your response was No go on to \#13)

11. If your response was YES to the above, please mark the category representing the number of experiences you had for the total year.....................

12. If you responded to the above, how beneficial was this experience in furthering your social work education?

\begin{tabular}{cccc}
$\begin{array}{c}0-3 \\
\mathrm{a}\end{array}$ & $\begin{array}{c}4-7 \\
\mathrm{~b}\end{array}$ & $\begin{array}{c}8-11 \\
\mathrm{c}\end{array}$ & $\begin{array}{c}12 \text {-or over } \\
\mathrm{d}\end{array}$ \\
$\begin{array}{l}\text { of no } \\
\text { benefit }\end{array}$ & $\begin{array}{c}\text { lacking } \\
\text { benefit }\end{array}$ & beneficial & $\begin{array}{l}\text { extremely } \\
\text { beneficial }\end{array}$ \\
\hline 1 & 2 & 3 & 4
\end{tabular}


In direct services were you provided:

13. Assignments that provided experiences to work with other community resources? (If your response was NO go on to \#16)

14. If your response was YES to the above, please mark the category representing the number of experiences you had for the total year....................... $0-3$

15. If you responded to the above, how beneficial was this experience in benefit beneflt furthering your social work education?

$\begin{array}{llll}1 & 2 & 4 & 5\end{array}$

SUPPORTING QUESTIONS: (Please mark only YES or NO)

16. Is direct services the primary area of your interest?

17. Was direct services a primary area of your need this past year at John Adams?

18. Do you feel more competent in direct services as a result of your experience this year at John Adams? 
In consultation were you provided experience:

19. Working with teachers and other school personnel regarding clients?

(If your response was No go on the \#22)

20. If your response was YES to the above, please mark the category representing the number of experiences you had for the total year........................ $0-3$

In consultation were you provided experience:

22. Working with personnel of other agencies regarding clients?

23. If your response was YES to the above, please mark the category representing the number of experiences you had for the

total year........................ 0-3

of no lacking

b

benefit

\section{8-11}

c

beneficial
If you responded to the above, how furthering your social work education?

$$
\text { benefit }
$$

2

2

3

3

\section{2-or over}

d

extremely beneficial 
In consultation were you provided experiences:

25. In instruction by your field instructor or other personnel provided by your field instructor in consultation?

(If your response was No go on to \#28)

26. If your response was YES to the above, please mark the category representing the number of experiences you had for the total year....................

$0-3$

a

of no benefit furthering your social work education?

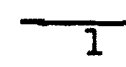

$4-7$

b

lacking benefit
$8-11$

c

beneficial 12-or over d

extremely beneficial

neutral

\section{2}

4

SUPPORTING QUESTIOIS: (Please mark only YES or NO)

28. Is consultation the primary area of your interest?

29. Was consultation a primary area of your need this past year at John Adams?

30. Do you feel more competent in consultation as a result of your experiences this year at John Adams? 
In program development:

31. Did you develop any program(s) to meet the needs of clients in your field placement?

(If your response was NO go on to \#34)

32. If your response was YES to the above, please mark the category representing the number of experiences you had for the total year......................... $0-3$

a

of no benefit
$4-7$

b

lacking

benefit
$8-11$

c

beneficial extremely beneficial 12-or over

d beneficial was this experience in furthering your social work education?

1 235

In program development:

34. Was any instruction provided by your field instructor or other personnel provided by your field instructor in program development?

(If your response was No go on to \#37)

35. If your response was IES to the above, please mark the category representing the number of experiences you had for the total year.........................

$\begin{array}{cccc}0-3 & 4-7 & 8-11 & 12-\text { or over } \\ a & b & c & d\end{array}$

36. If you responded to the above, how beneficial was this experience in furthering your social work education?

\begin{tabular}{llccc}
$\begin{array}{l}\text { of no } \\
\text { benefit }\end{array}$ & $\begin{array}{l}\text { lacking } \\
\text { benefit }\end{array}$ & beneficial & $\begin{array}{l}\text { extremely } \\
\text { beneficial }\end{array}$ & neutral \\
\hline 1 & 2 & 3
\end{tabular}


SUPPORTING QUESTIONS: (Please mark only YES or NO)

37. Is program development the primary area of your interest?

38. Was program development a primary area of your need this past year at John Adams?

39. Do you feel more competent in program development as a result of your experiences this year at John Adans? 
In supervision:

40. Did you have any experiences supervising other agency personnel; and/or, social work students while in your fleld placement at John Adams? (If your response was No go on to \#43)

41. If your response was YES to the above, please mark the category representing the number of experiences you had for the total year....................

42. If you responded to the above, how beneficial was this experience in furthering your social work education?

$$
\begin{array}{cc}
0-3 & 4-7 \\
a & b
\end{array}
$$

of no lacking benefit benefit
$8-11$

c

beneficial

extremely beneficial 12-or over

d

1 2345

In supervision:

43. Did you recelve any instruction by your field instructor or other personnel provided by your field instructor in supervision? (If your response was NO go on to $\# 46$ )

44. If your response was YES to the above, please mark the category representing the number of experiences you had for the total year....................

45. If you responded to the above, how beneficial was this experlence in furthering your social work education?

$\begin{array}{cc}0-3 & 4-7 \\ a & b\end{array}$

of no lacking benefit benefit
$8-11$

c

beneficial

neutral

extremely beneficial 12-or over

d

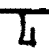


SUPPORTING QUESTIONS: (Please mark only YES or NO)

46. Is supervision the primary area of your interest? YES

47. Was supervision a primary area of your need this past year at John Adams?

48. Do you feel more competent in supervision as a result of your experience this year at John Adams? 
In teaching:

49. Did you have any experiences in teaching while in the field unit? YES (If your response was NO go on to \#52)

50. If your response was IES to the above, please mark the category representing the number of experlences you had for the

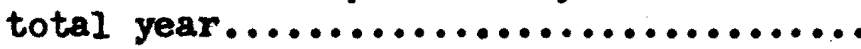

$$
0-3
$$

of no benefit

$$
\frac{4-7}{b}
$$

lacking benefit
$8-11$

c

beneficial

furthering your social work education?

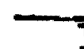

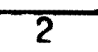

12-or over

d

extremely beneficial

neutral

In teaching:

52. Did you receive any instruction by your field instructor or other personnel provided by your fleld instructor in teaching? (If your response was NO go on to \#5b)

53. If your response was IES to the above, please mark the category representing the number of experiences you had for

the total year....................

54. If you responded to the above, how beneficial was this experience in furthering your social work education?

$\begin{array}{cccc}0-3 & 4-7 & 8-11 & 12-\text { or over } \\ \text { a } & \text { b } & \text { c } & d\end{array}$

of no lacking beneficial benefit benefit extremely beneficial

neutral 
SUPPCRTING QUESTIONS: (Please mark only YES or NO)

55. Is teaching the primary area of your interest?

56. Was teaching a primary area of your need this past year at John Adams?

57. Do you feel more competent in teaching as a result of your experiences this year at John Adams? 
Research:

58. Did you have experience in research in the field placement at John Adams?

(If your answer was No go on to \# 6I)

59. If your response was IDS to the above, please mark the category representing the number of experiences you had for the total year.....................
$0-3$

\section{of no}

benefit
4-7

b

lacking

benefit
$8-11$

c

beneficial

beneficial was this experience in

furthering your social work education?

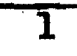

\begin{abstract}
2
\end{abstract}

3

extremely beneficial 12-or over d

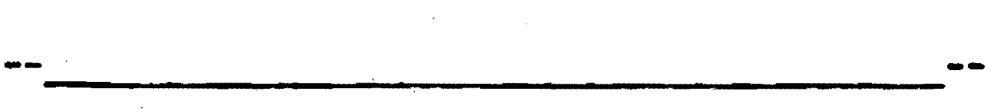

\section{Research:}

61. Did you recelve instruction in research by your field instructor or other personnel provided by your field instructor in research? (If your answer was No go on to $\# 64$ )

62. If your response was IFS to the above, please mark the category representing the number of experiences you had for the total year.....................

63. If you responded to the above, how beneficial was this experience in furthering your social work education?

\begin{tabular}{cccc}
$\begin{array}{c}0-3 \\
\mathrm{a}\end{array}$ & $\begin{array}{c}4-7 \\
\mathrm{~b}\end{array}$ & $\begin{array}{c}8-11 \\
\mathrm{c}\end{array}$ & $\begin{array}{c}12-\text { or over } \\
\mathrm{d}\end{array}$ \\
$\begin{array}{l}\text { of no } \\
\text { benefit }\end{array}$ & $\begin{array}{l}\text { lacking } \\
\text { benefit }\end{array}$ & beneficial & $\begin{array}{c}\text { extremely } \\
\text { beneficial }\end{array}$ \\
\hline 1 & 2 & 3 & 4
\end{tabular}


SUPPORTING QUESTIONS: (Please mark only IRS or NO)

64. Is regearch the primary area of your interest?

65. Was research a primary area of your need this past year at John Adams?

66. Do you feel more competent in research as a result of your experiences this year at John Adams?

THE END OF SECTION ONE 
PART I: SectIon II

OBJECTIVE B: TO PROVIDE INSTRUCTION TO GRADUATE STUDENTS THROUGH VARIOUS METHODS; WHICH INCLUDE INDIVIDUAL AND GROUP CONFERENCES, TAPE RECORDINOS OF GROUP AND INDIVIDUAL CONTACTS

WITH CLIINTS, PROCESS RECORDIMGS, AND YODELTNG OF FIEID INSTRUCTOR, AGENCY PERSONNEL AND

OTHER GRADUATE SOCIAL WORX STUDENTS AT JOHN ADANS HIGH SCHOOL.

\section{Individual conferences:}

67. Were you provided this type of instruction?

(If your answer 10 go on to "70)

68. If your response was YaS to the above, please mark the category representing the number of experiences you had for the total year.....................

69. If you responded to the above, how beneficial was this experience in furthering your social work education?

$\begin{array}{cccc}0-3 & 4-7 & 8-11 & 12 \text {-or over } \\ \text { a } & \text { b } & c & d\end{array}$

of no lacking beneficial extremely beneficial

neutral

benefit benefit beneficial

5

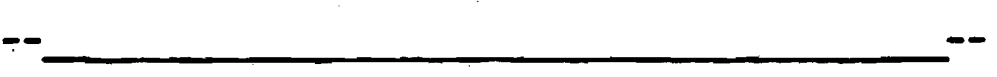

Group conferences:

70. Were you provided this type of instruction? (If your answer was NO go on to \#73)

71. If your response was YES to the above, please mark the category representing the number of experiences you had for the total year.....................

72. If you responded to the above, how beneficial was this experience in furthering your social work education?

$\begin{array}{cccc}0-3 & 4-7 & 8-11 & 12-\text { or over } \\ \text { a } & \text { b } & \text { c } & d\end{array}$

$\begin{array}{llll}\text { of no } & \text { lacking } & \text { beneficial } & \begin{array}{l}\text { extremely } \\ \text { beneflcial }\end{array}\end{array}$


73. Were you provided this type of instruction? (If your answer was NO go on to "76)

74. If your response was VIS to the above, please mark the category representing the number of experiences you had for the total year........................... $0-3$

12-or over d

75. If you responded to the above, how beneficial was this experience in furthering your social work education?

$\begin{array}{llll}\text { of no lacking } & \text { beneficial } & \begin{array}{l}\text { extremely } \\ \text { beneficial }\end{array} & \text { neutral } \\ \text { benefit } & \text { benefit }\end{array}$

\section{Process recordings:}

76. Were you provided this type of instruction? (If your answer was No go on to \#79)

77. If your response was WES to the above, please mark the category representing the number of expertences you had for the total year........................... $0-3$

$\begin{array}{cccc}0-3 & 4-7 & 8-11 & 12-\text { or over } \\ a & b & c & d\end{array}$

78. If you responded to the above, how beneficial was this experience in furthering your social work education?

$\begin{array}{ll}\text { of no lacking beneficial } & \begin{array}{l}\text { extremely neutral } \\ \text { beneficial }\end{array}\end{array}$

\begin{tabular}{llll} 
& & & \\
\hline & 3 & 4
\end{tabular}


79. Were you provided this type of instruction?

80. If your response was YES to the above, please mark the category representing the number of experiences you had for the total year......................

81. If you responded to the above, how beneficial was this experience in furthering your social work education?

$\begin{array}{cccc}0-3 & 4-7 & 8-11 & 12-\text { or over } \\ \text { a } & \text { b } & \text { c } & \text { d }\end{array}$

$\begin{array}{llll}\text { of no } & \text { lacking } & \text { beneficial } & \begin{array}{l}\text { extremely } \\ \text { beneficial }\end{array}\end{array}$ neutral

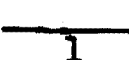

2

THE END OF SECTION TWO

THE BND OF PART I

THAK YOU. 


\section{INTRODUCTION}

The following questionnaire is an attempt to answer two basic questions:

1. Can a graduate school social work field instruction unit in public school social work on the elementary and secondary levels be evaluated?

2. If it can be evaluated, can an ongoing instrument be developed allowing for program and individual student evaluation?

Your name need not be signed to the questionnaire; your individual responses will be anonymous. Our only concern is with patterns projected by the combined responses of all participants.

The questionnaire is designed to study the functioning of the entire social work unit, rather than the performance of individuals within the unit. 


\section{JOHN ADAMS SOCIAL WORK UNIT}

Evaluation

Robert Roy, Unit Fleld Supervisor, has listed the following goal and objectives as the basis of the social work field experience at John Adems High School

Goal: To provide graduate social work students a training experience in social work that meets the needs and interests of the individual student. This will be accomplished through "School Social Work" in elementary (1-8) and secondary educational settings.

\section{Objectives :}

a. To provide training experiences in direct service, consultation, program development, supervision, teaching, and research.

b. To provide instruction to graduate students through various methods; which include Individual and group conferences; tape recordings of group and individual contact with clients; process recordings; modeling fleld instructor, agency personnel, and other social work students at John Adams High School.

c. To acquaint students with other resources in the community and how to utilize them in their performance as a school social worker.

d. To help students gain a better awareness of their self and how this understanding affects their performance as a social worker.

8. To provide training experiences for students in working with minority groups.

f. To expose students to the vital areas of John Adans High School in an effort to determine the effectiveness of that area for the performance of a school social worker. 


\section{OBNERAL IMSTRUCTIONS}

1. All questions must be answered according to the specific instructions presented.

2. There are four different sections.

3. There is no time limit for completing the questionnaire so please read and answer each question carefully and thoughtfully.

4. If you have any questions while completing the questionnaire, raise your hand for assistance.

5. Please mark all your responses on the answer sheet provided. If you change an answer, please erase your previous response completely. It is important that only one response is given for each question.

6. The numbers on the questionnaire correspond to the same numbers on the answer sheet. 
OBJECTIVE C: TO ACQUAINT STUDENTS WITH OTHER RESOURCES IN THE COMMUNITY AND HOW TO UTILIZE THEM IN THEIR PERFORMANCE AS A SCHDOL SOCIAL WORKER.

Were you acquainted with communtty resources and how they are used through:

1. Formal presentations by other personnel within the agency? (If your answer was No go on to \#4)

2. If your response was IDS to the above, please mark the category representing the number of experiences you have had for the total year..................

$0-3$ a

of no lacking beneficial
benefit benefit

12-or over

d

extremely beneficial

neutral beneficial was this experience in furthering your social work education?

\begin{tabular}{lllll}
\hline 1 & 2 & 3 & 4 & 5
\end{tabular}

Were you acquainted with community resources and how they are used through:

4. Formal field visits to other agencies?

YES

No

(If your answer was No go on to \#7)

5. If your response was YES to the above, please mark the category representing the number of experiences you have had for the total year........................ 0-3

4-7

b

c

12-or over

6. If you responded to the above, how beneficial was this experience in of no lacking beneficial benefit benefit extremely beneficial

neutral

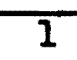

2

3

4 
Were you acquainted with community resources and how they are used through:

7. Experiences with clients requiring use of referral agency resources? YES ( If your answer was NO go on to \#10)

8. If your response was YES to the above, please mark the category representing the number of experiences you have had for the total year........................... $0-3$

4-7

c

12-or over d

9. If you responded to the above, how beneficial was this experience in of no lacking beneficial extremely beneficial

neutral furthering your social work education?

benefit benefit

\section{4} $-$

Were you acquainted with community resources and how they are used through:

10. Interaction with other unit students and social workers regarding community resources? (If your answer was No go on to \#13)

11. If your response was YES to the above, please mark the category representing the number of experiences you have had for the total year..................

12. If you responded to the above, how beneficial was this experience in furthering your social work education?

$\begin{array}{cccc}0-3 & \begin{array}{c}4-7 \\ \mathrm{~b}\end{array} & \begin{array}{c}8-11 \\ \mathrm{c}\end{array} & \begin{array}{c}12-\text { or over } \\ \mathrm{d}\end{array} \\ \begin{array}{c}\text { of no } \\ \text { benefit }\end{array} & \begin{array}{l}\text { lacking } \\ \text { benefit }\end{array} & \text { beneficial } & \begin{array}{l}\text { extremely } \\ \text { beneficial }\end{array}\end{array}$

2 
Were you acquainted with community resources and how they are used through:

13. Contact with the field instructor regarding community resources?

(If your answer was $N 0$ go on to \#16)

14. If your response was $\operatorname{VES}$ to the above, please mark the category representing the number of experiences you have had for the total year....................

$0-3$

\section{of no}

benefit
4-7

b

lacking

benelit
8-11

c

beneficial furthering your social work education?

12-or over

d

extremely beneficial 
OBJECTIVE D: TO HELP STUDENTS GAIN A BETTER AWARENESS OF THEIR SELF (PERSONAL GROWTH).

Did you gain self awareness trrough:

16. Conferences with field instructor? (If your answer was No go on to \#19)

17. If your response was YES to the above, please mark the category representing the number of experiences you have had for the total year.................

$\begin{array}{cccc}0-3 & 4-7 & 8-11 & 12-\text { or over } \\ a & b & c & d\end{array}$

18. If you responded to the above, how beneficial was this experience in furthering your social work education?

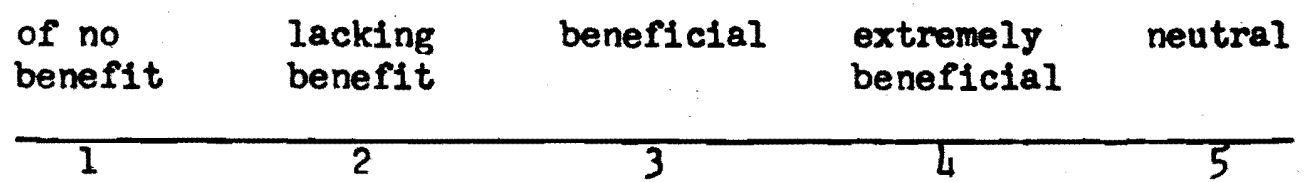

Did you gain self awareness through:

19. Experiences with clients and other social work experiences in the agency?

(If your answer was No go on to \#22)

20. If your response was VES to the above, please mark the category representing the number of experiences you have had for the total year......................

21. If you responded to the above, how of no beneficial was this experience in furthering benefit your social work education?

$\begin{array}{llll}1 & 3 & 4\end{array}$


22. Readings provided in the field?

(If your answer was NO go on to \#25)

YES

No

23. If your response was Yas to the above, please mark the category representing the number of experiences you have had for the total year..................

24. If you responded to the above, how beneficial was this experlence in further ing your social work education?
$0-3$
4-7
$8-11$
12-or over
d

$\begin{array}{llll}\text { of no lacking beneficial } & \begin{array}{l}\text { extremely neutral } \\ \text { beneflcial }\end{array}\end{array}$

Did you gain self awareness through:

25. Interaction with peers?

(If your answer was NO go on to \#28)

YES

NO

26. If your response was TIS to the above, please mark the category representing the number of experiences you have had for the total year..................

27. If you responded to the above, how beneficial was this experlence in furthering your social work education?

$0-3$

a

or no

benefit

lacking

benefit
4-7

b

2
$8-11$

c

beneficial extremely beneficial 12-or over

d

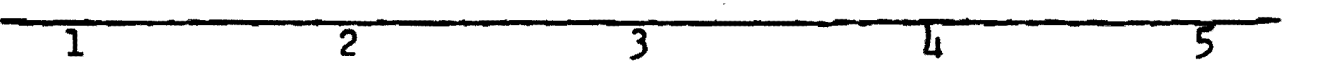


Did you gain self awareness through:

28. Formal presentations by field instructor and other instruction or speakers?

(If your answer was $\mathrm{NO}$ go on to \#31)

29. If your response was YES to the above, please mark the category representing the number of experiences you have had for the total year..................

30. If you responded to the above, how beneficial was this experience in furthering your social work education?

\begin{tabular}{|c|c|c|c|c|}
\hline $\begin{array}{c}0-3 \\
a\end{array}$ & $\begin{array}{c}4-7 \\
b\end{array}$ & $\begin{array}{c}8-11 \\
c\end{array}$ & $\begin{array}{l}\text { 12-or over } \\
\text { d }\end{array}$ & \\
\hline $\begin{array}{l}\text { of no } \\
\text { benefit }\end{array}$ & $\begin{array}{l}\text { lacking } \\
\text { benefit }\end{array}$ & beneficial & $\begin{array}{l}\text { extremely } \\
\text { beneficial }\end{array}$ & neutral \\
\hline
\end{tabular}


OBJECTIVE E: TO PROVIDE TRAINING EXPERIENCES FOR STUDENTS IN WORKING WITH MINORITY GROUPS.

Were you provided training experiences working with minority groups through:

31. Contact with minorfty group clients?

(If your answer was NO go on to \#34)

32. If your response was IES to the above, please mark the category representing the number of experlences you have had for the total year...................

$0-3$ a

$\begin{array}{ll}\text { of no lacking } \\ \text { benefit } & \text { benefit }\end{array}$

8-11

c

beneficial

2 extremely beneficial

12-or over

d beneficial was this experience in furthering your social work education?

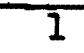
1 $-$

Were you provided training experiences working with minority groups through:

34. Contact with minority teachers or other minority school personnel? YES (If your answer was No go on to \#37)

NO

35. If your response was IES to the above, please mark the category representing the number of experiences you have had for the total year.....................

$\begin{array}{cccc}0-3 & 4-7 & 8-11 & 12-\text { or over } \\ a & b & c & d\end{array}$

36. If you responded to the above, how beneficial was this experience in furthering your social work education?

\begin{tabular}{llll}
$\begin{array}{l}\text { of no } \\
\text { benefit }\end{array}$ & $\begin{array}{l}\text { lacking } \\
\text { benefit }\end{array}$ & beneficial & $\begin{array}{l}\text { extremely neutral } \\
\text { beneficial }\end{array}$ \\
\hline
\end{tabular}


Were you provided training experiences working with minority groups through:

37. Interaction or relationships with fellow unit minority students?

(If your answer was NO go on to \#40)

38. If your response was YES to the above, please mark the category representing the number of experiences you have had for the total year....................

$\begin{array}{cccc}0-3 & 4-7 & 8-11 & 12-\text { or over } \\ \text { a } & \text { b } & c & d\end{array}$

39. If you responded to the above, how beneficial was this experience in furthering your social work education?

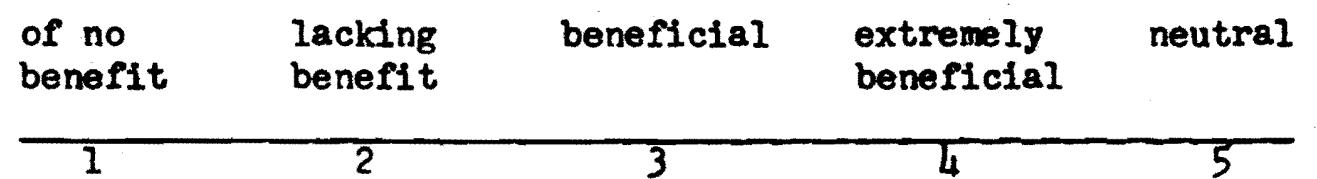

Were you provided training experiences working with minority groups through:

40. Readings concerning minority groups or problems? (If your answer was No go on to \#43)

41. If your response was YES to the above, please mark the category representing the number of experiences you have had for the total year..................

42. If you responded to the above, how beneficial was this experience in furthering your social work education?

$\begin{array}{cccc}0-3 & 4-7 & 8-11 & 12-\text { or over } \\ a & \text { b } & c & d\end{array}$

$\begin{array}{llll}\begin{array}{l}\text { of no } \\ \text { benefit }\end{array} & \begin{array}{l}\text { lacking benefit } \\ \text { beneficial }\end{array} & \begin{array}{l}\text { extremely } \\ \text { beneficial }\end{array}\end{array}$

\begin{tabular}{llll}
1 & & & \\
\hline & 3 & 4
\end{tabular}


Were you provided training experiences working with minority groups through:

43. Instruction in minority issues by field instructor or other personnel provided by your fleld instructor in this area? (If your answer was no go on to $\# 46$ )

44. If your response was IDS to the above, please mark the category representing the number of experiences you have had for the total year...................

45. If you responded to the above, how benerlicial was this experience in furthering your social work education?

$0-3$

a

of no

benefit

4-7

b

lacking

benefit
8-11

beneficial

2

END OF SECTION THREE 
PART II: Section IV

OBJECTIVE F: FOLLOWING ARE SEVERAL VITAL AREAS OF JOHN ADAMS HIGH SCHDOL. IF YOU HAVE WORKED WTTH ANT

OF THESE AREAS PLEASE EVALUATE THAT AREA ACCORDTNG TO YOUR ESTIMATION OF ITS WORTH FOR THE GRADUATE STUDENT SECKIMO INVOLVEMENT IN SCHOOL SOCIAL WORK.

Did you work with:

46. General Education (GenEd) teams?

TES

No

47. If you responded IISS to the above, how beneflcial do you think this area was for your school social work training?

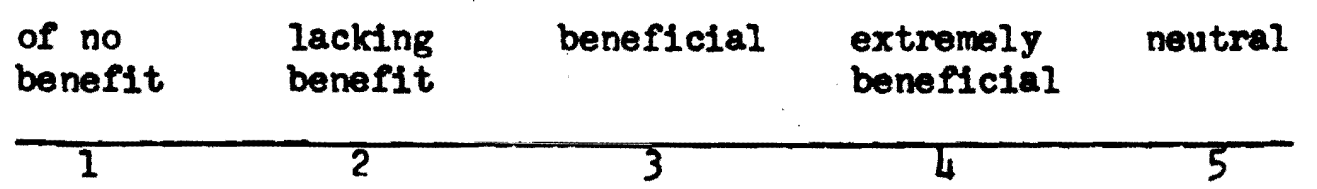

48. Would you recommend this area for continued use in training graduate students in school social work?

Did you work with:

49. School administrators? (If your answer $\mathrm{NO} g 0$ on to \#52)

50. If you responded VES to the above, how beneficial do you think this area was

of no lacking beneficial
benefit
for your school social work training?

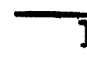

$$
2
$$

51. Would you recommend this area for continued use in training graduate students in school social work? 
52. School counselors? (If your answer was $\mathrm{NO}$ go on to \#55)

YES

beneficial

of no lacking

benefit

beneflcial do you think this area was for benefit

2
1
(2)

(2) extremely beneficial

neutral

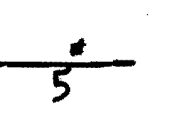

54. Would you recommend this area for continued use in training graduate students in school social work? $-\infty$

Did you work with:

55. School social worker? (If your answer was No go on to \#58)

YES

beneficial

of no lacking

benefit benefit beneficial do you think this area
your school social work education?

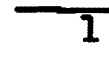

2 
58. Research department? (If your answer was $10 \mathrm{go}$ on to final question)

YES

no

59. If you responded Ins to the above, how of no beneficial do you think this area was for benefit no lacking

beneficial

extremely benefictal neutral your school social work education?

60. Would you recomend this area for continued use in training graduate students in school social work?

IrSS

No

QUESTION: DO YOU HUVE ANY QUESTIONS OR COMANTS REGARDING EITHER THE DESION OR CONTENT OF THE QUESTIONMAIRE? IF SO, PLEASE RESFOND ON THE BACK OF YOUR ANSWER SHETS.

END OF QUESTIONRAIRE. 